\title{
Girişimcilik Kapasitesinin Bulanık Mantık Yaklaşımıyla Ölçülmesi ve Bir Uygulama
}

\author{
Enver CCAKIN \\ KOSGEB İmir Kuzey Müdürlüğü \\ enver.cakin@kosgeb.gov.tr, ORCID:0000-0001-7523-8193
}

Öz

$\mathrm{Bu}$ çalışmada bulanık mantık yaklaşımı kullanılarak girişimcilik kapasitesinin ölçülmesi amaçlanmıştır. Ayrıca bulanık mantık yaklaşımı ile klasik yöntem karşılaştırmalı olarak incelenmiştir. Çalışma kapsamında analiz edilen veriler girişimcilik eğitimine katılan kişilerden anket tekniği ile toplanmıştır. Araştırma sonuçlarına göre; girişimcilik eğitimi verilen üç sınıfın genel girişimcilik kapasitelerinin düşük düzeyde olduğu sonucuna ulaşılmıştır. Ayrıca üç sınıfın da temel iş yetenekleri, pazarlama yetenekleri, finans yetenekleri ve teknik yeteneklerinin düşük ve orta düzey oldukları belirlenmiştir. Bununla birlikte bulanık mantık yaklaşımının klasik yöntemlere göre daha esnek ve dilsel değişkenler ile insan düşünce sistemini dikkate alan daha tutarlı bir yöntem olduğu vurgulanmıştır.

Anahtar Kelimeler: Girişimcilik, Girişimcilik Kapasitesi, Bulanık Mantık

JEL Sınıflandırma Kodları: M13, C44

\section{Fuzzy Logic Approach for Measuring Entrepreneurship Capacity and an Application ${ }^{1}$}

\begin{abstract}
In this study, it is aimed to measure entrepreneurial capacity by using fuzzy logic approach. Moreover, fuzzy logic approach and classical method have been studied comparatively. The data analyzed within the scope of the study are collected from the person who participated in entrepreneurship training with survey technique. According to the results of the research, the general entrepreneurship capacities of three classes given entrepreneurship training are low. In addition, it is determined that core business skills, marketing skills, financial skills and technical skills of three classes are low and moderate. Furthermore, it is emphasized that fuzzy logic approach is more flexible than classical method and it is a more consistent method that considers the linguistic variables and the human thoughts.
\end{abstract}

Keywords: Entrepreneurship, Entrepreneurship Capacity, Fuzzy Logic JEL Classification Codes: M13, C44

\footnotetext{
${ }^{1}$ Extended abstract is presented at the end of the article.

Geliş Tarihi (Received): 26.09.2018 - Kabul Tarihi (Accepted): 26.06.2019
}

Atıfta bulunmak için/Cite this paper:

Çakın, E. (2019). Girişimcilik kapasitesinin bulanık mantık yaklaşımıyla ölçülmesi ve bir uygulama. Çankırı Karatekin Üniversitesi İİBF Dergisi, 9 (1), 245-275. 


\section{Giriş}

Son yıllarda ülkelerin gelişmişlik düzeyleri, girişimcilik faaliyetlerine verdikleri önem, girişimcilere verdiği değer, girişimcilerin ürettiği yeni ve katma değerli ürünler ile oluşturdukları iş ortamları ile belirlenmektedir. Küresel ölçekte söz sahibi olmak isteyen ülkeler girişimcilik faaliyetlerini destekleyerek ve nitelikli girişimcilerin sayısını sürekli ve düzenli olarak arttırarak rakiplerine karşı önemli rekabet avantajı yaratabilmektedir. Günümüzde ülkelerin de işletmeler gibi rekabet halinde olduğu düşünüldüğünde, girişimciliğin ülkelerin odaklanması gereken önemli politikalardan birisi olduğu kaçınılmazdır. Bir ülkede girişimcilik faaliyetlerinin etkin bir şekilde gerçekleşmesi ve başarılı bir şekilde sürdürülmesi ülkelerin sahip olduğu insan kaynağının girişimcilik yeteneklerine ve girişimcilik kapasitesine bağlıdır.

Girişimcilik faaliyetleri, başarılı girişimciler sayesinde toplumda bir değişim ve dönüşüm süreci başlatılarak ülkelerin ekonomilerine önemli katkılar sağlamaktadır. Girişimci, fırsatları algılayan, değerlendiren, risk alan ve aklındaki fikirleri yenilikçi ürün ve hizmetlere dönüştüren kişidir. Klasik üretim faktörleri arasında sayılan girişimcilik, doğal kaynaklar, emek ve sermayeyi verimli bir şekilde bir araya getirerek ve kullanarak katma değerli işler üreten kişilerdir. Tüm bu özellikler dikkate alındığında, herkesin girişimci olamayacağı ve girişimci olabilmek için birtakım teknik ve yönetsel yetkinliklere sahip olmaları gereği açıktır.

Ülkelerin girişimcilik kapasitesini ölçen en önemli performans göstergelerinden biri erken dönem girişimcilik endeksidir. Bir ülkede ne kadar kişinin girişimci olmaya niyeti olduğunu ve ne kadar kişinin bu niyetlerini hayata geçirebildiklerini ölçmektedir. Ülkemizin erken dönem girişimcilik endeksi 2006-2007-2008 yıllarında ortalama \% 6 iken 2010 yılında \% 8.59'a yükselmiş, bu yükseliş 2011 yılında da devam ederek yaklaşık \% 12 seviyesine çıkmıştır. 2012 yılında \% 12 oranı tekrar yakalanmış olsa da 2013 yılında \% 10 seviyesine gerilemiştir. 2014 yılında bu oranda önemli bir artış yaşanarak \% 19 seviyesi yakalanmıştır. 2015 yllında bu oran \% 17.4'e ve 2016 yılında da \% 16.1'e düşmüştür. (Global Entrepreneurship Monitor, 2014-2016 ve Girişimcilik Stratejisi ve Eylem Planı, 2015-2018). Görüldüğü üzere, belirli dönemlerde düşüş yaşanmışsa da 2006 yılından itibaren ciddi bir artış kaydedilmiştir. Bu oranının çeşitli politikalar ile sürekli olarak arttırılması önemli bir konudur. Bunun için ülkeler sahip oldukları insan kaynağının girişimcilik kapasitesini düzenli olarak ölçmek, girişimcilik kapasitesini etkileyen faktörleri belirlemek ve kişilerin zayıf noktalarını tespit ederek çeşitli eğitimler ile o zayıf yönleri güçlü konuma dönüştürmeleri gerekmektedir.

$\mathrm{Bu}$ düşünce ile bu çalışmada, bulanık mantık yaklaşımı ile girişimcilik kapasitesinin ölçülmesi amaçlanmıştır. Ayrıca bulanık mantık yaklaşımı ile elde edilen sonuçlar klasik yöntemler ile karşılaştırmalı olarak incelenmiş ve bulanık 
mantık yaklaşımının güçlü noktalarına değinilmiştir. İlk bölümde girişimcilik ve girişimcilik kapasitesinin ölçümüne ilişkin teorik çerçeve incelenmiş, ikinci bölümde ise bulanık mantık yaklaşımı ele alınmıştır. Son olarak ise, girişimcilik eğitimine katılan kişilerin farklı yetenekleri ele alınarak bulanık mantık yaklaşımı ile kişilerin girişimcilik kapasitesini ölçen uygulama bölümüne yer verilmiştir.

\section{Girişimcilik ve Girişimcilik Kapasitesinin Ölçülmesi}

Girişimcilik son yıllarda her gün konuşulan güncel konulardan biridir. Politikacılar, ekonomistler, akademisyenler, öğrenciler gibi birçok kesim sıklıkla girişimcilikten bahsetmektedirler. Girişimciliğin önemini vurgulamak için dünyanın her yerinde seminerler, konferanslar, workshoplar gibi faaliyetler organize edilmektedir. Çünkü birçok çalışma göstermiştir ki; girişimcilik, küreselleşme sürecinde ülkelerin ekonomik gelişmesinde ve sürdürülebilir rekabet avantaj1 elde etmesinde en iyi stratejilerden birisidir (Keat vd., 2011, s. 206). Girişimcilik, yeni ürünleri, yeni hizmetleri, yeni iş modellerini tasarlamak, yürütmek ve pazara sunmaktır. Riskleri fırsatlara dönüştürmek için işleri oluşturma, düzenleme ve denetleme yeteneği olarak karakterize edilmektedir (Baloch, 2017, 286). Girişimcilik genellikle kendi işini kurma, kendi işinin sahibi olma süreci olarak bilinmektedir. Farklı disiplinlerden gelen birçok kişi girişimcilik üzerine çalıştığından standart bir tanım yapmak zordur. Bir ekonomiste göre, katma değerli ürün üretmek için kaynakların biraraya getirilmesidir. Bir psikoloğa göre, hedeflere ulaşma ve başarı elde etme süreci, bir iş adamına göre de, kaynakları iyi işler yapmak için kullanan, israfı azaltan, yeni iş hacimleri oluşturan, tehdit unsuru ve agresif rakiplerdir (Hisrich vd., 2005 aktaran Wei Ni, 2012, s. 16). Girişimci olmak, bir anda ve aniden olunan bir olgu değildir, belirli bir zaman gerektirir. Kendi işinin sahibi olma olasılığının ilk düşüncesinden yeni bir işe başlamaya kadar olan oldukça uzun bir süreçtir. Brixy vd. (2008), girişimcilik sürecini işletme sahibi olma düşüncesi aşaması, keşfetme aşaması, işletme kurma aşaması ve girişimcilik aşaması olmak üzere dört sürece ayırmışlardır (Brixy vd., 2008, ss. 6-7). Curral vd. (2013) ise yaptıkları çalışmada girişimcilik sürecini, fırsatları tanıma, bir iş girişimine karar verme, kaynakları toplama, yeni bir iş girişimini gerçek anlamda başlatma, başarılı bir iş kurma ve son olarak ödül/başarı/kazanç elde etme olmak üzere altı aşamada incelemişlerdir. Girişimcilik sürecini etkin bir şekilde yürütmek ve başarılı bir işletme kurmak için kişinin bazı yeteneklere sahip olması ve girişimcilik kapasitesinin yüksek olması gerekmektedir. Aksi takdirde girişimcilik faaliyetleri başarısız bir şekilde sonuçlanacak ve kaynaklar boş yere harcanacaktır. $\mathrm{Bu}$ nedenle girişimcilik faaliyetlerine başlamak isteyen bir kişinin girişimcilik kapasitesinin iyi değerlendirilmesi ve ölçülmesi gerekmektedir. Girişimcilik kapasitesi, girişimcinin öngörülü hareket etme yeteneği, yaratıcı davranış, önsezi ve sezgisel davranışlara sahip olması, yeni firsatlara karşı tetikte beklemesi ve yeni bir iş girişimi oluşturmak için gerekli kaynakları belirlemesi olarak ifade edilebilmektedir (Zhang, 2013, s.7). Zahra (2011) ise girişimcilik kapasitesini, 
firsatları keşfetmek ve firsatlardan yararlanmak için içsel ve dışsal süreçlerin algılanması, belirlenmesi, şekillendirilmesi ve senkronize edilmesi olarak tanımlamıştır.

Literatür incelendiğinde, girişimcilik eğiliminin ve girişimcilik kapasitesinin ölçüldüğü, girişimcilik eğiliminin çeşitli değişkenler açsından analiz edildiği, girişimciliği etkileyen ve belirleyen faktörlerin araştırıldığı çeşitli çalışmalar gözlemlenmiştir. Girişimcilik kapasitesinin ölçümünde girişimciliği açıklayan doğru değişkenlerin belirlenmesi tutarlı bir analiz için önemlidir. Girişimcilik ölçümünün en önemli belirleyicilerinden biri olan girişimcilik yeteneklerini analiz eden çalışmalar incelendiğinde, girişimcilik yeteneklerinin sınıflandırıldığı görülmektedir. Cooney (2012) yaptığı çalışmada girişimcilik yeteneklerini, teknik beceri, yönetim becerisi ve girişimcilik becerisi olmak üzere üçe ayırmışıtır. Teknik beceri olarak, işlemleri yönetme, iletişim, tasarım, araştırma-geliştirme ve çevreyi gözlemleme becerisini, yönetim becerisi olarak planlama, karar verme, motive olma, pazarlama, finans, satı̧ becerisi ve girişimcilik becerisi olarak da disiplinli olma, risk alma, yenilikçilik, değişim odaklı ve kararlı olma becerisini dikkate almışlardır. Kutzhanova vd. (2009), girişimcilerin kapasitelerini dört temel yeteneğinin oluşturduğunu belirtmişlerdir. Ürün/hizmet becerisi olan teknik beceri, işletmeyi yönetme ve faaliyetleri yürütme becerisi olan yönetim becerisi, firsatları tanımlama becerisi olan girişimcilik becerisi ve duygusallık, yaratıcılık, kendinin farkında olma gibi kişilik yetenekleri olarak analiz etmişlerdir.

Girişimcilik eğilimlerinin ve girişimcilik kapasitelerinin çeşitli değişkenlere göre analiz edildiği çalışmalarda ise demografik, psikolojik, sosyal ve çevresel faktörlerin dikkate alındığı belirlenmiştir. Asamani ve Mensah (2013), yaptıkları çalışmada Gana'da okuyan üniversite öğrencilerinin girişimcilik eğilimini ölçmüşler ve çeşitli değişkenlere göre karşılaştırmışlardır. Çalışmalarının sonucunda, öğrencilerin yüksek düzeyde girişimcilik kapasitelerinin olduğunu, liderlik yeteneği, iş yapma performansı, başarı güdüsü ve risk alma yeteneği yüksek olan kişilerin girişimcilik düzeylerinin daha yüksek olduğunu belirlemişlerdir. Çetin ve Taşdemir (2017), yaptıkları çalışmada bireysel yenilikçilik yeteneği yüksek olan bireylerin girişimcilik kapasitelerinin daha yüksek olduğunu ve bunun da girişimcilik niyetini olumlu yönde etkilediğini vurgulamışlardır. Girişimcilik kapasitesini ölçmek için firsatları görme, yaratıcılık, sorun çözme, liderlik ve iletişim becerisi, ürün ve hizmetleri iyileştirme, profesyonel ilişkiler kurma değişkenlerini kullanmışlardır. Araştırmanın sonucunda, girişimcilik kapasitesinin ortanın üstünde olduğu sonucuna ulaşmışlardır. Aksoy ve Yalçınsoy (2017), yaptıkları çalışmada 2301 üniversite öğrencisinin girişimcilik düzeylerini belirlemişlerdir. Analizleri sonucunda, öğrencilerin girişimcilik kapasitelerinin yeterli olduğunu ve girişimcilik konusundaki bilinç düzeylerinin iyi bir noktada olduğunu tespit etmişlerdir. Yılmaz ve Sünbül (2009), yaptıkları çalışma ile üniversite öğrencilerinin girişimcilik kapasitesini ölçen bir girişimcilik ölçeği 
geliştirmişlerdir. Girişimcilik düzeylerini, çok düşük, düşük, orta, yüksek ve çok yüksek girişimcilik olmak üzere beş gruba ayırmışlardır. Girişimciliğin kapasitesinin ölçümünde kişilik özellikleri ve girişimcilik yeteneklerini dikkate alan sorular geliştirmişlerdir. 474 öğrenci ile yaptıkları çalışmaları sonucunda, üniversite öğrencilerinin girişimcilik kapasitelerinin yüksek olduğu sonucuna ulaşmışlardır. Chunxia (2011), Çin'de kendi işinde çalışan 603 kişi ile yaptığı çalışmada girişimcilik kapasitesini ölçen bir değerlendirme endeksi geliştirmiştir. Doğrulayıcı faktör analizi (DFA) ile yaptığı analizler sonucunda, firsatları belirleme ve geliştirme yeteneği, organizasyonun ihtiyaç duyacağı içsel ve dişsal tüm kaynakları belirleme yeteneği, çevreyle ilişki kurma yeteneği, kurumsal stratejileri belirleme yeteneği ve müşterilere, çalışanlara, tedarikçilere verilen sözlerin yerine getirme yeteneği gibi değişkenler ile girişimcilik kapasitesini ölçmüştür. Girişimcilik düzeyini, çok zayıf, biraz zayıf, zayıf, orta, iyi ve çok iyi olmak üzere altı düzeyde incelemiştir.

Davis vd. (2015), yaptıkları çalışmada girişimcilik kapasitesinin en önemli belirleyicilerinden biri olan kişinin girişimcilik zihniyeti düzeyini ölçen bir model geliştirmişlerdir. Girişimcilik kapasitesini ölçmede kişilik özellikleri ve yetenekler olmak üzere 2 ana boyutta toplam 14 değişkeni dikkate almışlardır. Kişilik özellikleri kapsamında, bağımsız olma, informel yapıda olma, inovatif, risk alma, eylem odaklı olma, hırs ve başarma isteği değişkenlerini, yetenek boyutu kapsamında ise gelecek odaklılık, fikir üretme, fikirleri uygulama, kendine güven, iyimserlik, azim ve duyarlılık değişkenlerini incelemişlerdir. Mamabolo vd. (2017), yaptıkları çalışmada girişimciler için gerekli ve girişimcilerin sahip olması gereken temel yetenekleri DFA ile belirlemişlerdir. Analizleri sonucunda girişimcilerin, insan kaynakları, finans, pazarlama yetenekleri, teknik beceri, liderlik, sosyal olma ve iletişim ile start-up becerilerine sahip olmaları gerektiğini vurgulamışlardır. $\mathrm{Bu}$ becerilerin, girişimcilerin kapasitesini ölçmede ve girişimcilik eğitimlerinde bir araç olarak kullanılabileceğini belirtmişlerdir. Silva de Souza vd. (2017), yaptıkları çalışmada girişimcilik potansiyelini ölçmede kullanılabilecek bir ölçek geliştirmişler ve DFA ile de faktörleri belirlemişlerdir. Firsatları belirleme, azimli olma, etkin olma, hedefleri belirleme, bilgi elde etme, planlama, kontrol, ikna etme, sosyal olma ve ilişki kurma yeteneklerinin girişimcilik potansiyelini ölçmede kullanılabileceğini göstermiştir. Coduras vd. (2016), yaptıkları çalışmada sosyolojik, psikolojik ve yönetimsel faktörleri göz önüne alarak girişimcilik kapasitesini ölçen bir puanlama sistemi geliştirmişlerdir. Kişinin her soruya yönelik verdiği cevaplara göre her bir boyutun puanının hesaplamışlar ve son olarak ise bu puanları birleştirerek bireyin girişimcilik puanını belirlemişlerdir.

Bu çalışmada da girişimcilik puanları likert ölçeğinden yararlanılarak belirlenmiş ve bulanık mantık yaklaşımına uyarlanmıştır. Literatürde likert ölçeği ile bulanık mantık yaklaşımını bütünleştiren çeşitli çalışmalar mevcuttur. Vonglao (2017), yaptığı çalışmada gizli değişsenleri ölçmede kullanılan Likert ölçeğini 
iyileştirmede bulanık mantık yaklaşımını uygulamıştır. Bulanık likert ölçeğinin klasik likert ölçeğine göre analizlerde daha uygun olduğunu ve düşük standart sapma ile normal dağılıma daha yakın olduğunu belirtmiştir. Bıyan ve Bircan (2018), yaptıkları çalışma da Likert ölçeğinin dezavantajlarını gidermek için tip-1 ve tip-2 bulanık mantık yaklaşımlarını likert ölçeğine uyarlamışlar ve bunun için bir web sitesi geliştirmişlerdir. Bulanık mantık yaklaşımı ile toplanan verilerin daha iyi ve daha hassas olabileceğini göstermişlerdir. Güner ve Çomak (2014), yaptıkları çalışmada öğrencilerin matematik dersine yönelik tutumlarını bulanık mantık yöntemi ile incelemişler ve sonuçları klasik yöntem ile karşılaştırmışlardır. Gil vd. (2015), yaptıkları çalışmada belirsiz insan düşüncelerini probleme yansıtmada bulanık puanlama tabanlı bir anket geliştirmişlerdir.

Girişimcilik kapasitesinin mikro düzeyde bireysel olarak ölçen, çeşitli demografik, sosyal, psikolojik, çevresel gibi faktörlere göre değerlendiren çalışmaların yanısıra girişimcilik kapasitesini makro boyutta ülkeler ve bölgeler bazında ölçen çalışmalar da mevcuttur. Bu kapsamdaki en önemli çalışmalardan biri Küresel Girişimcilik Monitörü (Global Entrepreneurship Monitor-GEM) projesidir. GEM ilk olarak 1999 yılında Amerika'daki Babson College ve İngiltere'deki London Business School'un işbirliği sonucu ortaya çıkmış bir projedir ve her yıl ülkelerin girişimcilik kapasitelerini ayrıntılı olarak analiz ederek ülkeleri faktör odaklı, etkinlik odaklı ve inovasyon odaklı olmak üzere üç grupta incelemektedir. Girişimcilik kapasitesini ölçmede, finans, hükümet politikaları, girişimcilik eğitimleri, ticaret ve yasal altyapı, içsel pazar dinamikleri, pazar sorunları, fiziksel altyapı ve kültürel/sosyal normlar gibi değişkenleri dikkate almaktadır. Ülkemiz 2016/2017 raporuna göre orta sınıfta olan "etkinlik odaklı" grupta yer almakta ve özellikle erken dönem girişimcilik sıralamasında 64 ülke arasında 14. sıradadır (GEM, 2016/2017). Diğer bir çalışma ise, Amerika'da faaliyet gösteren The Global Entrepreneurship and Development Institute tarafından ülkelerin girişimcilik ekosisteminin sağllğını ölçen Küresel Girişimcilik Endeksi (Global Entrepreneurship Index-GEI) adlı bir rapordur. Küresel Girişimcilik Endeksi çalışması, firsatları algılama, start-up yeteneği, risk alma yeteneği, a ğ kurma yeteneği, kültür, girişimci olma kolaylığı, teknoloji absorbsiyonu, insan sermayesi, rekabet, ürün inovasyonu, süreç inovasyonu, büyüme, uluslararasılaşma ve risk sermayesi değişkenleri ile ölçüm yapmaktadır. 2018 yılı raporuna göre ülkemiz 137 ülke arasında 37. sırada yer almaktadır (GEI, 2018). Tüm çalışmalar incelendiğinde, çeşitli değişkenlerin dikkate alınarak ve çeşitli yöntemler uygulayarak girişimcilik kapasitesini ölçen farklı modeller önerildiği görülmektedir. Girişimcilik sürecinin belirsizlikler içerdiği düşünüldüğünde bulanık mantık yaklaşımı farklı bir alternatif olarak karşımıza çıkmaktadır. 


\section{Bulanık Mantık}

Bulanık mantık yaklaşımı, insan düşünce sistemi ile uyumlu bir şekilde çalışan ve belirsiz süreçleri tutarlı bir şekilde modelleyen bir yaklaşımdır. Bulanık mantık, bilgiyi ve insan aklını bilgisayarların işleyebileceği bir şekilde temsil etmek için tasarlayan mantığın bir dalıdır (Yadav vd., 2014, s. 55). Bulanık mantık kavramı ilk olarak 1965 yılında Zadeh tarafından yapılan "Fuzzy Sets" adlı çalışma ile tanıtılmıştır (Zadeh, 1965). Daha sonra Zadeh (1973) ile Mamdani ve Assilian (1975) tarafından yapılan çalışmalar ile gelişim göstermiştir. Zadeh, "Yaklaşık Muhakeme" kavramını ortaya atmış ve belirsiz mantıksal ifadeler ile belirsiz çıkarımlar yapmak için belirsiz verileri kullanabilen algoritmaların oluşturulabileceğini başarılı bir şekilde göstermiştir. Ayrıca bulanık mantık yaklaşımının tüm karmaşık sistemlerde kullanılmasının faydalı olabileceğini düşünmüştür (Sarkar vd., 2012, s. 2). Bulanık mantık, bulanık küme teorisine ve üyelik fonksiyonlarına dayanmaktadır. Bulanık küme teorisi, kısmi üyelik dereceleri üzerine kurulmuştur. Geleneksel küme teorisinde, bir değer 0 veya 1 , doğru ya da yanlış, iyi veya kötü gibi kesinlikle bir kümeye aittir. Ancak bulanık küme teorisinde, bir birey \% 65 bir kümeye ait olabilir ya da bir eylem \% 75 oranında doğru olabilmektedir (Azimjonov vd., 2016, s. 88). Aşağıdaki Şekil 1'de bulanık ve klasik kümeler gösterilmektedir.

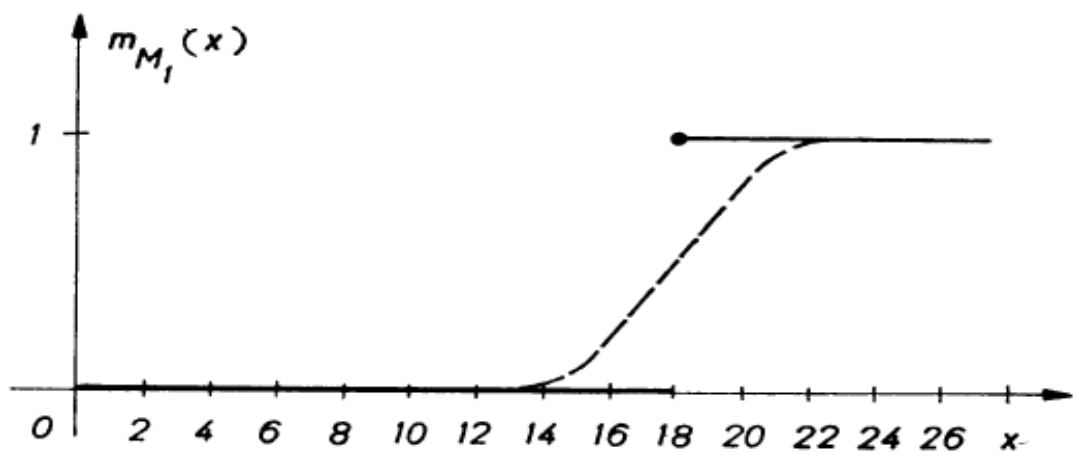

Şekil 1: Bulanık ve Klasik Kümeler

Kaynak: Bandemer ve Gottwald, 1995, ss. 2-3

18 yaşını yetişkinlik dönemine geçiş olarak tanımladığımızda; klasik küme teorisinde 16 yaşındaki birisi genç, 20 yaşındaki birisi ise yetişkin olarak kabul edilmektedir. Ancak bulanık küme teorisinde, 16 ve 20 yaşlarındaki kişiler belirli bir dereceye kadar genç, belirli bir dereceye kadar da yetişkin sınıfına dahil olmaktadır (Bandemer ve Gottwald, 1995, ss. 2-3). Her bir kümeye aitlik derecesi de üyelik fonksiyonları ile belirlenmektedir. Üyelik fonksiyonu, girdi uzayındaki her bir noktanın üyelik değerini 0 ile 1 arasında tanımlayan bir eğridir. Birçok farklı tipte üyelik fonksiyonu olmasına rağmen uygulamada genellikle üçgensel 
ve yamuksal üyelik fonksiyonları kullanılmaktadır. Üçgensel ve yamuksal üyelik fonksiyonları aşağıdaki Şekil 2'de, eşitlikler ise (1) ve (2) nolu formüllerde yer almaktadir (Thakre vd., 2017, ss. 132-133).

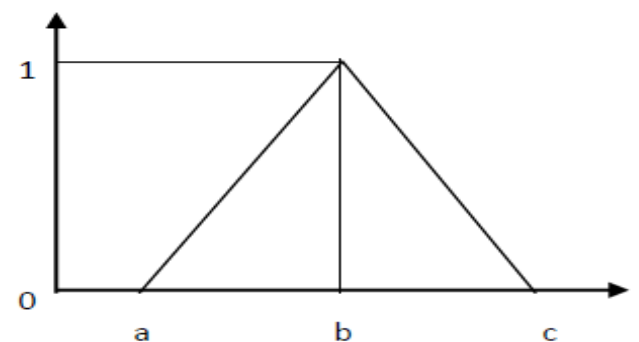

Üçgensel Üyelik Fonksiyonu

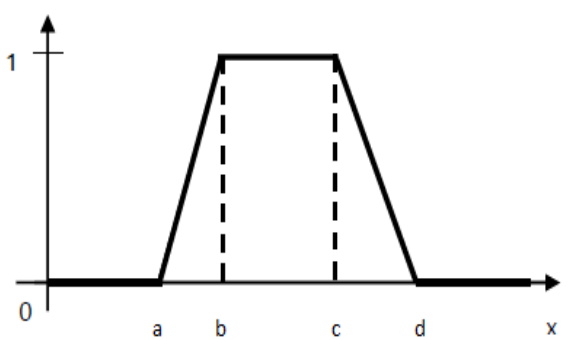

Yamuksal Üyelik Fonksiyonu

\section{Şekil 2: Üçgensel ve Yamuksal Üyelik Fonksiyonları}

Kaynak: Thakre vd., 2017, 132-133

Üçgensel üyelik fonksiyonunun $(\mathrm{a}, \mathrm{b}, \mathrm{c})$ olmak üzere üç parametresi varken, yamuksal üyelik fonksiyonunun $(\mathrm{a}, \mathrm{b}, \mathrm{c}, \mathrm{d})$ olmak üzere dört adet parametre değeri bulunmaktadır.

$$
\begin{aligned}
& \mu_{A}(x)=\left\{\begin{array}{ccc}
\frac{x-a}{b-a} & , & a<x<b \\
1 & , & x=b \\
\frac{c-x}{c-b} & , & b<x<c \\
0 & , & x \leq a, x \geq c
\end{array}\right\} \\
& \mu_{A}(x)=\left\{\begin{array}{ccc}
\frac{x-a}{b-a} & , & a<x<b \\
1 & , & b \leq x \leq c \\
\frac{c-x}{c-b} & , & c<x<d \\
0 & , & x \leq a, x \geq d
\end{array}\right\}
\end{aligned}
$$

Bulanık mantık ve bulanık küme teorisinin en önemli uygulamalarından birisi, bulanık çıkarım sistemidir. Bulanık çıkarım sistemi, insan bilgi ve deneyimlerinden yararlanarak oluşturulan "eğer-ise" kurallarını içeren bilgi tabanlı veya kural tabanlı sistemlerdir. Bir bulanık çıkarım sistemi, bulanıklaştırma, kural tabanlı çıkarım ve durulaştırma olmak üzere üç aşamadan oluşmaktadır (Surya vd., 2016, ss. 72). Aşağıdaki Şekil 3'de bulanık çıkarım sistemi görülmektedir. 


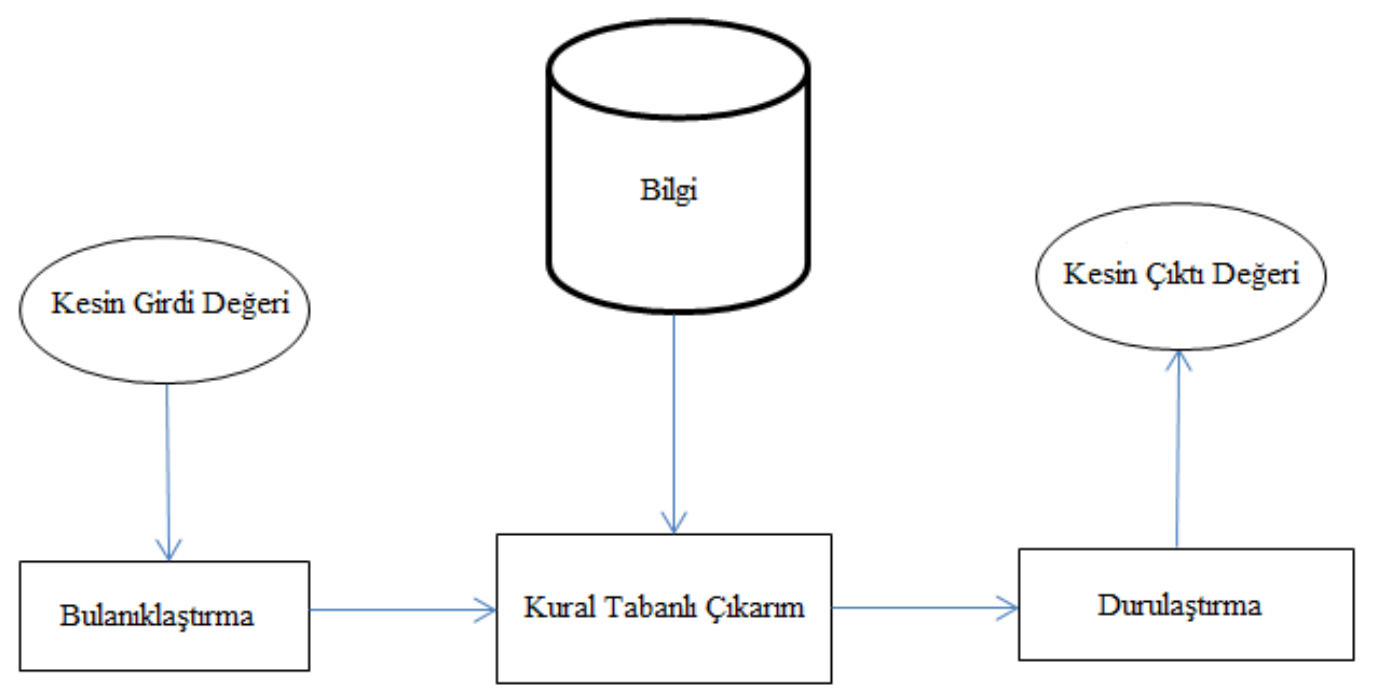

Şekil 3: Bulanık Çıkarım Sistemi

Kaynak: Upadhyay ve Gautam, 2015, s. 94

Bulanıklaştırma katmanında, kesin değerler uygun üyelik fonksiyonları yardımıyla bulanık girdi değerlerine dönüştürülmektedir (Upadhyay ve Gautam, 2015, s. 95). Kural tabanlı çıkarım aşamasında, bulanık kurallar olarak adlandırılan "eğer-ise" kural mekanizması ile girdi ve çıktı değişkenleri ilişkilendirilmektedir. Tüm kurallar eşzamanlı olarak çalışıp sonuç üretmektedirler. Örneğin; $x=A$ ise $y=B$ kuralında $A$ ve $B$ dilsel değişkenler, $x$ girdi ve $y$ ise çıktı değişkenidir (Das ve Mukherjee, 2017, s. 54). Kural tabanlı çıkarım için genellikle Mamdani tipi çıkarım ve Takagi-Sugeno tipi çıkarım olmak üzere iki yöntem kullanılmaktadır. Mamdani tipi model çok kolay oluşturulmakta ve insan davranışlarına çok uygundur. İlk defa bir buhar motorunun kontrolü amacıyla uygulanmıştır. Hem girdiler hem de çıktı değişkeni üyelik fonksiyonu ile gösterilmektedir. Takagi-Sugeno tipi bulanık çıkarım sisteminde ise ilk defa 1985 yılında kullanılmaya başlanmış ve hemen hemen Mamdani tipi çıkarım sistemi ile aynıdır. Tek farkı çıktı üyelik fonksiyonlarıdır. Takagi-Sugeno tipi bulanık çıkarım sisteminde çıktı üyelik fonksiyonları sadece lineer veya sabittir (Yılmaz ve Arslan, 2005, 515-516). Son aşamada ise, bulanık değerlerin kesin değerlere dönüştürüldüğü durulaştırma işlemi uygulanmaktadır. Durulaştırma işlemi için genellikle, maksimumların ortalaması ve ağırlık merkezi yöntemi kullanılmaktadır (Korol ve Korodi, 2011, s. 99).

\section{Uygulama}

\subsection{Araştırmanın Amacı ve Yöntemi}

Bu çalışmada bulanık mantık yaklaşımı ile girişimcilik kapasitesinin ölçülmesi ve klasik yöntem ile karşılaştırılması amaçlanmıştır. Girişimcilik kapasitesini ölçmek 
amacıyla analiz edilen tüm veriler KOSGEB tarafından düzenlenen uygulamalı girişimcilik eğitimlerine katılan girişimci adaylarından anket ile toplanmıştır. Çalışma kapsamında oluşturulan anket iki bölümden oluşmaktadır. İlk bölümde cinsiyet, yaş, medeni hal, eğitim durumu gibi demografik sorular yer almaktadır. İkinci bölümde ise girişimcilik kapasitesini ölçmede yararlanılan girişimcilik yeteneklerine ait sorular mevcuttur. Girişimcilik yeteneği olarak, temel iş yetenekleri, pazarlama yeteneği, finans yeteneği ve teknik yetenek olmak üzere dört temel değişken dikkate alınmıştır. Anketin oluşturulmasında Mamabolo vd. (2017) tarafından yapılan çalışmadan faydalanılmıştır. Temel iş yeteneklerini ölçmek için dört soru, pazarlama yeteneğini ölçmek için dört soru, finans yeteneğini ölçmek için üç soru ve teknik yeteneği ölçmek için üç soru bulunmaktadır. Girişimcilik kapasitesini ölçmek için sorulan sorular 5'li likert ölçeğinde (1=Kesinlikle katılmıyorum, 5= Kesinlikle katılıyorum) hazırlanmıştır. Girişimcilik eğitimi kapsamında 3 sınıf belirlenmiştir. Her sınıfta 30 kişi eğitim almakta ve toplamda 90 kişiden veri toplanmıştır. Herbir sınıfın ayrı ayrı olmak üzere temel iş yetenekleri, pazarlama yetenekleri, finans yetenekleri ve teknik yetenekleri ile genel girişimcilik kapasitelerinin düzeyleri belirlenmiştir.

\subsection{Araştırma Bulguları}

\subsubsection{Frekans Analizi}

Araştırmaya katılan kişilere ait demografik verilere ilişkin sonuçlar aşağıdaki Tablo 1'de yer almaktadir.

Tablo 1: Değişkenlere İliş kin Frekans Analizi

\begin{tabular}{|c|c|c|c|}
\hline \multicolumn{2}{|r|}{ Değişkenler } & Sayı & Yüzde \\
\hline \multirow{2}{*}{ Cinsiyet } & Kadın & 55 & 61,1 \\
\hline & Erkek & 35 & 38,9 \\
\hline \multirow{4}{*}{ Yaş } & 20-30 yaş arası & 35 & 38,9 \\
\hline & $31-40$ yaş arası & 36 & 40,0 \\
\hline & 41-50 yaş arası & 17 & 18,9 \\
\hline & 51 ve üstü & 2 & 2,2 \\
\hline \multirow{4}{*}{ Eğitim } & İlkokul-Ortaokul & 9 & 10,0 \\
\hline & Lise-Meslek Lisesi & 25 & 27,8 \\
\hline & Üniversite & 47 & 52,2 \\
\hline & Lisansüstü & 9 & 20 \\
\hline \multirow{2}{*}{$\begin{array}{c}\text { Medeni } \\
\text { Hal }\end{array}$} & Bekar & 46 & 51,1 \\
\hline & Evli & 44 & 48,9 \\
\hline
\end{tabular}


Tablo 1 incelendiğinde; araştırmaya katılan kişilerin çoğunluğunu kadınlar oluşturmaktadır. Ayrıca büyük çoğunluk 20 ve 40 yaş arası kişiler ile lise ve üstü mezuniyeti olan kişilerden meydana gelmektedir. Medeni hal bakımından ise bekar ve evli kişilerin sayıları birbirine eşittir.

\subsubsection{Faktör Analizi ve Güvenilirlik Analizi}

Araştırma kapsamında girişimcilik kapasitesini ölçmek için oluşturulan ölçeğin geçerlilik ve güvenilirliklerini belirlemek için faktör analizi yapılmış ve Cronbach's Alpha katsayıları incelenmiştir. Faktör analizi kapsamında KMO değerinin 0,5 değerinin üzerinde olması gerekmektedir. Güvenilirlik katsayısı Cronbach's Alpha değerinin de 0,60 ve üzeri olması beklenmektedir (Kalayc1, 2010, 322-405).

Tablo 2: Faktör ve Güvenilirlik Analizi

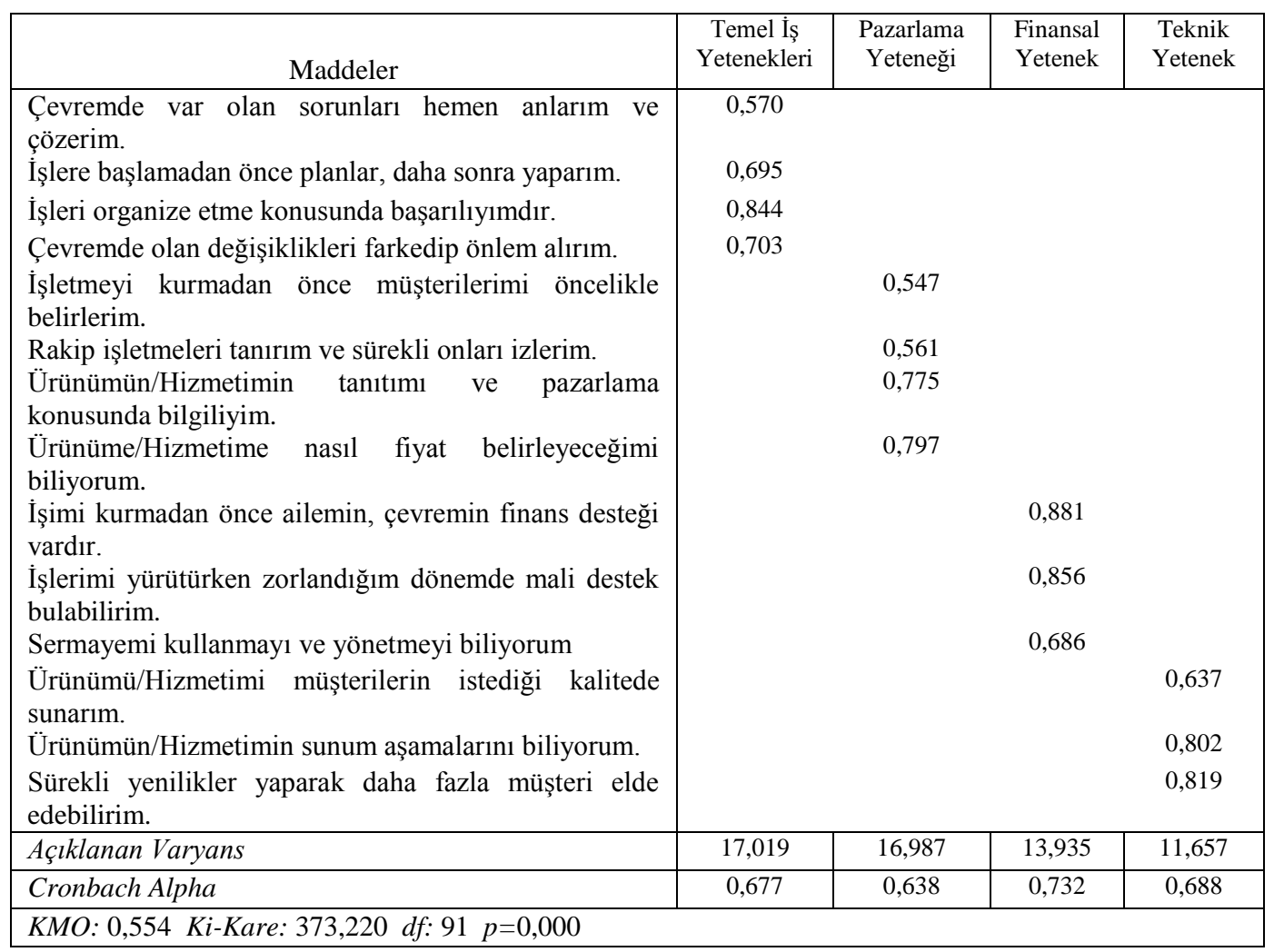

Faktör analizinde varimax rotasyonu uygulanmıştır. Faktör yükünün herbir madde için 0,40 ve üstü olmasına dikkat edilmiştir. Tablo 2 incelendiğinde; temel iş yetenekleri altında dört madde, pazarlama yeteneği altında dört madde, finans yeteneği altında üç madde ve teknik yetenek altında üç madde olmak üzere toplam 
dört faktörün elde edildiği görülmektedir. Faktörler toplam varyansın \% 60’ını oluşturmaktadır.

\subsubsection{Temel İş Yeteneği Düzeyinin Bulanık Mantık Yaklaşımıyla Ölçülmesi}

Herbir girişimciye ait performans puanı anketteki sorulara verilen cevapların toplamı ile belirlenmiştir. Likert ölçeğinde herbir soruya verilen puan en düşük 1 ve en yüksek 5 olabilmektedir. Temel iş yeteneği dört madde ile ölçüldüğünden bu değişken kapsamında bir kişi en az 4 ve en yüksek 20 puan alabilmektedir. Bu değişken kapsamında üçgensel üyelik fonksiyonu kullanılmış ve düşük, orta, yüksek olmak üzere 3 küme belirlenmiştir. Herbir dilsel değişkenin üyelik fonksiyonları aşağıda Şekil 4'de görülmektedir.

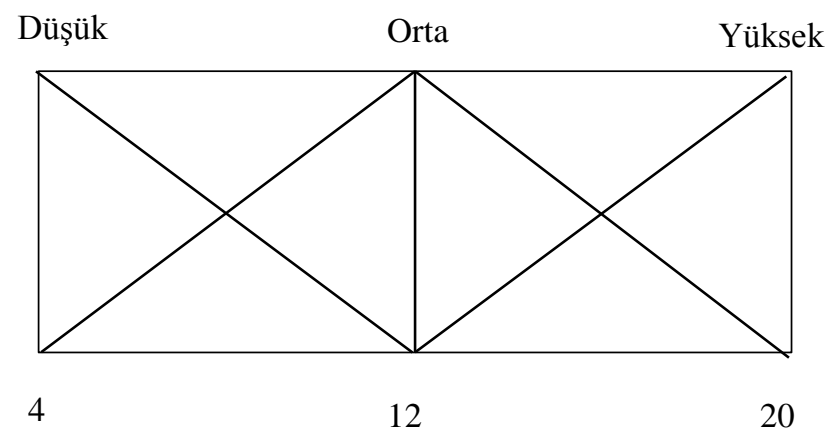

Şekil 4: Temel İş Yeteneği Değişkenine Ait Üyelik Fonksiyonları

$$
\begin{aligned}
& \mu_{\text {dissuk }}=\left\{\begin{array}{ccc}
0 & , & x \geq 12 \\
\frac{12-x}{8} & , & 4<x<12 \\
1 & , & x=4
\end{array}\right\} \quad \mu_{\text {orta }}=\left\{\begin{array}{ccc}
0, & x=4, x=20 \\
\frac{x-4}{8} & , & 4<x<12 \\
1 & , & x=12 \\
\frac{20-x}{8} & , & 12<x<20
\end{array}\right\} \\
& \mu_{\text {yüksek }}=\left\{\begin{array}{ccc}
0 & , & x \leq 12 \\
\frac{x-12}{8} & , & 12<x<20 \\
1 & , & x=20
\end{array}\right\}
\end{aligned}
$$

Temel iş yeteneği değişkeni çerçevesinde herbir sınıftaki herbir girişimciye ait puanlar hesaplanmış ve puanlara ait üyelik dereceleri aşağıdaki Tablo 3'de görülmektedir. 
Tablo 3: Temel İş Yeteneği Değişkenine İlişkin Üyelik Dereceleri

\begin{tabular}{|c|c|c|c|c|c|c|c|c|c|c|c|c|}
\hline \multirow{2}{*}{ G } & \multicolumn{4}{|c|}{ 1. Sinif } & \multicolumn{4}{|c|}{ 2. Sinif } & \multicolumn{4}{|c|}{ 3. Sinif } \\
\hline & $\mathrm{P}$ & D & $\mathrm{O}$ & Y & $\mathrm{P}$ & D & $\mathrm{O}$ & Y & $\mathrm{P}$ & D & $\mathrm{O}$ & Y \\
\hline 1 & 4 & 1 & 0 & - & 4 & 1 & 0 & - & 4 & 1 & 0 & - \\
\hline 2 & 5 & 0.875 & 0.125 & - & 4 & 1 & 0 & - & 5 & 0.875 & 0.125 & - \\
\hline 3 & 6 & 0.750 & 0.250 & - & 5 & 0.875 & 0.125 & - & 5 & 0.875 & 0.125 & - \\
\hline 4 & 6 & 0.750 & 0,250 & - & 5 & 0.875 & 0.125 & - & 5 & 0.875 & 0.125 & - \\
\hline 5 & 7 & 0.625 & 0.375 & - & 5 & 0.875 & 0.125 & - & 5 & 0.875 & 0.125 & - \\
\hline 6 & 7 & 0.625 & 0.375 & - & 6 & 0.750 & 0.250 & - & 6 & 0.750 & 0.250 & - \\
\hline 7 & 7 & 0.625 & 0.375 & - & 6 & 0.750 & 0.250 & - & 6 & 0.750 & 0.250 & - \\
\hline 8 & 7 & 0.625 & 0,375 & - & 6 & 0.750 & 0.250 & - & 7 & 0.625 & 0.375 & - \\
\hline 9 & 8 & 0.500 & 0.500 & - & 6 & 0.750 & 0.250 & - & 7 & 0.625 & 0.375 & - \\
\hline 10 & 8 & 0.500 & 0.500 & - & 7 & 0.625 & 0.375 & - & 8 & 0.500 & 0.500 & - \\
\hline 11 & 9 & 0.375 & 0.625 & - & 7 & 0.625 & 0.375 & - & 8 & 0.500 & 0.500 & - \\
\hline 12 & 9 & 0.375 & 0.625 & - & 7 & 0.625 & 0.375 & - & 8 & 0.500 & 0.500 & - \\
\hline 13 & 9 & 0.375 & 0.625 & - & 7 & 0.625 & 0.375 & - & 8 & 0.500 & 0.500 & - \\
\hline 14 & 11 & 0.125 & 0.875 & - & 7 & 0.625 & 0.375 & - & 8 & 0.500 & 0.500 & - \\
\hline 15 & 11 & 0.125 & 0.875 & - & 8 & 0.500 & 0.500 & - & 8 & 0.500 & 0.500 & - \\
\hline 16 & 11 & 0.125 & 0.875 & - & 8 & 0.500 & 0.500 & - & 8 & 0.500 & 0.500 & - \\
\hline 17 & 12 & 0 & 1 & - & 8 & 0.500 & 0.500 & - & 9 & 0.375 & 0.625 & - \\
\hline 18 & 12 & 0 & 1 & - & 8 & 0.500 & 0.500 & - & 9 & 0.375 & 0.625 & - \\
\hline 19 & 13 & - & 0.875 & 0.125 & 8 & 0.500 & 0.500 & - & 9 & 0.375 & 0.625 & - \\
\hline 20 & 13 & - & 0.875 & 0.125 & 8 & 0.500 & 0.500 & - & 10 & 0.250 & 0.750 & - \\
\hline 21 & 14 & - & 0.750 & 0.250 & 9 & 0.375 & 0.625 & - & 10 & 0.250 & 0.750 & - \\
\hline 22 & 14 & - & 0.750 & 0.250 & 9 & 0.375 & 0.625 & - & 10 & 0.250 & 0.750 & - \\
\hline 23 & 14 & - & 0.750 & 0.250 & 9 & 0.375 & 0.625 & - & 10 & 0.250 & 0.750 & - \\
\hline 24 & 16 & - & 0.500 & 0.500 & 9 & 0.375 & 0.625 & - & 10 & 0.250 & 0.750 & - \\
\hline 25 & 16 & - & 0.500 & 0.500 & 10 & 0.250 & 0.750 & - & 11 & 0.125 & 0.875 & - \\
\hline 26 & 17 & - & 0.375 & 0.625 & 10 & 0.250 & 0.750 & - & 11 & 0,125 & 0.875 & - \\
\hline 27 & 17 & - & 0.375 & 0.625 & 11 & 0.125 & 0.875 & - & 12 & - & 1 & 0 \\
\hline 28 & 17 & - & 0.375 & 0.625 & 11 & 0.125 & 0.875 & - & 13 & - & 0.875 & 0.125 \\
\hline 29 & 18 & - & 0.250 & 0.750 & 12 & - & 1 & 0 & 14 & - & 0.750 & 0.250 \\
\hline 30 & 18 & - & 0.250 & 0.750 & 13 & - & 0.875 & 0.125 & 14 & - & 0.750 & 0.250 \\
\hline
\end{tabular}

G: Girişimci, P: Puan, D: Düşük, O: Orta, Y: Yüksek

Herbir puana ait üyelik dereceleri belirlendikten sonra çıktı değerini elde etmek için min-max çıkarım yöntemi kullanılmıştır. Durulaştırma yöntemi olarak da, ağırlıklı ortalama yöntemi uygulanmıştır. Ağırlıklı ortalama yönteminde, üyelik 
dereceleri ile kümelerin orta değerleri çarpılıp toplanarak üyelik derecelerinin toplamına bölünür (Užga-Rebrovs ve Kul̦ešova, 2017, s. 27). Aşağıdaki Tablo 4'de temel iş yeteneği değişkenine ait min-max çıkarım ile durulaştırma sonuçları mevcuttur. Temel iş yeteneği değişkeni değerlendirildiğinde; en fazla puan 1. sinıfin, daha sonra 3. sinıfin son olarak ise 2. sinıfin puanı gelmektedir. 1. sinıf orta kümeye daha yakınken, 2. sınıf düşük kümeye daha yakındır. 3. sınıf ise düşük ile orta arasındadır şeklinde değerlendirilebilir. Tüm sınıfların temel iş yeteneklerinin yüksek sınıfına çıkarılmasına, özellikle de 2. sınıfın temel iş yeteneklerini arttıracak şekilde eğitilmelerine önem verilmelidir.

Tablo 4: Temel İş Yeteneği Değişkenine Ait Min-Max Çıkarım

\begin{tabular}{|l|l|l|c|c|c|}
\hline Sinıflar & Kümeler & \multicolumn{1}{|c|}{ Min. Değerler } & $\begin{array}{c}\text { Min-Max } \\
\text { Çıkarım }\end{array}$ & $\begin{array}{c}\text { Durulaştırılmış } \\
\text { Değer }\end{array}$ & Sonuç \\
\hline \multirow{3}{*}{ 1. Sinıf } & Düşük & $(0 / 0.125 / 0.375 / 0.5)$ & 0.5 & \multirow{2}{*}{10.4} & \multirow{2}{*}{ Orta } \\
\cline { 2 - 4 } & Orta & $(0.125 / 0.25 / 0.375 / 0.5)$ & 0.5 & & \\
\cline { 2 - 4 } & Yüksek & $(0.125 / 0.25)$ & 0.25 & & \multirow{3}{*}{ Düşük } \\
\hline \multirow{3}{*}{ 2. Sinıf } & Düşük & $(0.125 / 0.25 / 0.375 / 0.5)$ & 0.5 & & \multirow{2}{*}{ Orta } \\
\cline { 2 - 4 } & Orta & $(0 / 0.125 / 0.25 / 0.375)$ & 0.375 & & \\
\cline { 2 - 4 } & Yüksek & $(0 / 0.125)$ & 0.125 & & \\
\hline \multirow{3}{*}{ 3. Sinıf } & Düşük & $(0.125 / 0.25 / 0.375 / 0.5)$ & 0.5 & & \\
\cline { 2 - 4 } & Orta & $(0 / 0.125 / 0.25 / 0.375)$ & 0.375 & & \\
\cline { 2 - 4 } & Yüksek & $(0.125 / 0.25)$ & 0.25 & & \\
\hline
\end{tabular}

4.2.4. Pazarlama Yeteneği Düzeyinin Bulanık Mantık Yaklaşımıyla Ölçülmesi

Pazarlama yeteneği dört madde ile ölçüldüğünden bu değişken kapsamında bir kişi en az 4 ve en yüksek 20 puan alabilmektedir. Bu değişken kapsamında üçgensel üyelik fonksiyonu kullanılmış ve düşük, orta, yüksek olmak üzere 3 küme belirlenmiştir. Herbir dilsel değişkenin üyelik fonksiyonları Şekil 5'de görülmektedir.

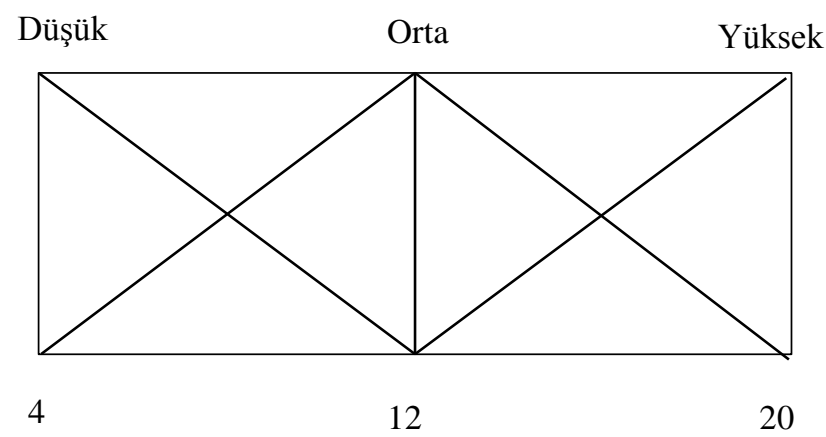

Şekil 5: Pazarlama Yeteneği Değişkenine Ait Üyelik Fonksyionları 


$$
\begin{aligned}
& \mu_{\text {düsük }}=\left\{\begin{array}{ccc}
0 & , & x \geq 12 \\
\frac{12-x}{8} & , & 4<x<12 \\
1 & , & x=4
\end{array}\right\} \quad \mu_{\text {orta }}=\left\{\begin{array}{ccc}
0, & x=4, x=20 \\
\frac{x-4}{8} & , & 4<x<12 \\
1, & x=12 \\
\frac{20-x}{8} & , & 12<x<20
\end{array}\right\} \\
& \mu_{\text {yüksek }}=\left\{\begin{array}{ccc}
0 & , & x \leq 12 \\
\frac{x-12}{8} & , & 12<x<20 \\
1 & , & x=20
\end{array}\right\}
\end{aligned}
$$

Pazarlama yeteneği değişkeni çerçevesinde herbir sınıftaki herbir girişimciye ait puanlar ve puanlara ait üyelik dereceleri aşağıdaki Tablo 5'de görülmektedir.

\begin{tabular}{|c|c|c|c|c|c|c|c|c|c|c|c|c|}
\hline \multirow{2}{*}{ G } & \multicolumn{4}{|c|}{ 1. Sinif } & \multicolumn{4}{|c|}{ 2. Sinif } & \multicolumn{4}{|c|}{ 3. Sinif } \\
\hline & $\mathrm{P}$ & $\mathrm{D}$ & $\mathrm{O}$ & Y & $\mathrm{P}$ & $\mathrm{D}$ & $\mathrm{O}$ & $Y$ & $\mathrm{P}$ & D & $\mathrm{O}$ & Y \\
\hline 1 & 4 & 1 & 0 & - & 4 & 1 & 0 & - & 4 & 1 & 0 & - \\
\hline 2 & 4 & 1 & 0 & - & 4 & 1 & 0 & - & 5 & 0.875 & 0.125 & - \\
\hline 3 & 4 & 1 & 0 & - & 6 & 0.750 & 0.250 & - & 5 & 0.875 & 0.125 & - \\
\hline 4 & 4 & 1 & 0 & - & 6 & 0.750 & 0.250 & - & 6 & 0.750 & 0.250 & - \\
\hline 5 & 4 & 1 & 0 & - & 7 & 0.625 & 0.375 & - & 6 & 0.750 & 0.250 & - \\
\hline 6 & 6 & 0.750 & 0.250 & - & 7 & 0.625 & 0.375 & - & 6 & 0.750 & 0.250 & - \\
\hline 7 & 6 & 0.750 & 0.250 & - & 7 & 0.625 & 0.375 & - & 6 & 0.750 & 0.250 & - \\
\hline 8 & 6 & 0.750 & 0.250 & - & 8 & 0.500 & 0.500 & - & 6 & 0.750 & 0.250 & - \\
\hline 9 & 6 & 0.750 & 0.250 & - & 8 & 0.500 & 0.500 & - & 7 & 0.375 & 0.625 & - \\
\hline 10 & 6 & 0.750 & 0.250 & - & 8 & 0.500 & 0.500 & - & 7 & 0.375 & 0.625 & - \\
\hline 11 & 7 & 0.625 & 0.375 & - & 8 & 0.500 & 0.500 & - & 8 & 0.500 & 0.500 & - \\
\hline 12 & 8 & 0.500 & 0.500 & - & 8 & 0.500 & 0.500 & - & 8 & 0.500 & 0.500 & - \\
\hline 13 & 8 & 0.500 & 0.500 & - & 8 & 0.500 & 0.500 & - & 8 & 0.500 & 0.500 & - \\
\hline 14 & 8 & 0.500 & 0.500 & - & 8 & 0.500 & 0.500 & - & 8 & 0.500 & 0.500 & - \\
\hline 15 & 8 & 0.500 & 0.500 & - & 9 & 0.375 & 0.625 & - & 8 & 0.500 & 0.500 & - \\
\hline 16 & 8 & 0.500 & 0.500 & - & 9 & 0.375 & 0.625 & - & 8 & 0.500 & 0.500 & - \\
\hline 17 & 8 & 0.500 & 0.500 & - & 9 & 0.375 & 0.625 & - & 10 & 0.250 & 0.750 & - \\
\hline 18 & 8 & 0.500 & 0.500 & - & 9 & 0.375 & 0.625 & - & 10 & 0.250 & 0.750 & - \\
\hline 19 & 8 & 0.500 & 0.500 & - & 10 & 0.250 & 0.750 & - & 11 & 0.125 & 0.875 & - \\
\hline 20 & 8 & 0.500 & 0.500 & - & 10 & 0.250 & 0.750 & - & 11 & 0.125 & 0.875 & - \\
\hline 21 & 9 & 0.375 & 0.625 & - & 10 & 0.250 & 0.750 & - & 12 & - & 1 & 0 \\
\hline
\end{tabular}

Tablo 5: Pazarlama Yeteneği Değişkenine İlişkin Üyelik Dereceleri 
Tablo 5: Pazarlama Yeteneği Değişkenine İlişkin Üyelik Dereceleri (Devamı)

\begin{tabular}{|c|c|c|c|c|c|c|c|c|c|c|c|c|}
\hline \multirow{2}{*}{$\mathrm{G}$} & \multicolumn{4}{|c|}{ 1. Sinif } & \multicolumn{4}{c|}{ 2. Sinif } & \multicolumn{4}{c|}{ 3. Sinif } \\
\cline { 2 - 14 } & $\mathrm{P}$ & $\mathrm{D}$ & $\mathrm{O}$ & $\mathrm{Y}$ & $\mathrm{P}$ & $\mathrm{D}$ & $\mathrm{O}$ & $\mathrm{Y}$ & $\mathrm{P}$ & $\mathrm{D}$ & $\mathrm{O}$ & $\mathrm{Y}$ \\
\hline 22 & 9 & 0.375 & 0.625 & - & 11 & 0.125 & 0.875 & - & 12 & - & 1 & 0 \\
\hline 23 & 10 & 0.250 & 0.750 & - & 11 & 0.125 & 0.875 & - & 12 & - & 1 & 0 \\
\hline 24 & 10 & 0.250 & 0.750 & - & 12 & - & 1 & 0 & 14 & - & 0.750 & 0.250 \\
\hline 25 & 10 & 0.250 & 0.750 & - & 12 & - & 1 & 0 & 14 & - & 0.750 & 0.250 \\
\hline 26 & 11 & 0.125 & 0.875 & - & 13 & - & 0.875 & 0.125 & 15 & - & 0.625 & 0.375 \\
\hline 27 & 11 & 0.125 & 0.875 & - & 13 & - & 0.875 & 0.125 & 16 & - & 0.500 & 0.500 \\
\hline 28 & 12 & - & 1 & 0 & 15 & - & 0.625 & 0.375 & 17 & - & 0.375 & 0.625 \\
\hline 29 & 12 & - & 1 & 0 & 16 & - & 0.500 & 0.5 & 19 & - & 0.125 & 0.875 \\
\hline 30 & 16 & - & 0.500 & 0.500 & 16 & - & 0.500 & 0.5 & 19 & - & 0.125 & 0.875 \\
\hline
\end{tabular}

Herbir puana ait üyelik dereceleri belirlendikten sonra çıktı değerini elde etmek için kullanılan min-max çıkarım yöntemi ile elde edilen sonuçlar ile durulaştırma değerleri Tablo 6'da yer almaktadır.

Tablo 6: Pazarlama Yeteneği Değişkenine Ait Min-Max Çıkarım

\begin{tabular}{|c|c|c|c|c|c|}
\hline Siniflar & Kümeler & Min. Değerler & $\begin{array}{c}\text { Min-Max } \\
\text { Çıkarım }\end{array}$ & $\begin{array}{l}\text { Durulaştırılmış } \\
\text { Değer }\end{array}$ & Sonuç \\
\hline \multirow{3}{*}{ 1. Sinif } & Düşük & $0.125 / 0.25 / 0.375 / 0.5$ & 0.5 & \multirow[t]{3}{*}{ 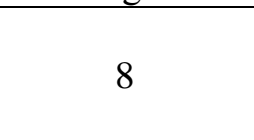 } & \multirow{3}{*}{ Orta } \\
\hline & Orta & $0 / 0.25 / 0.375 / 0.5$ & 0.5 & & \\
\hline & Yüksek & $0 / 0$ & 0 & & \\
\hline \multirow{3}{*}{ 2. Sinif } & Düşük & $0.125 / 0.25 / 0.375 / 0.5$ & 0.5 & \multirow{3}{*}{11.27} & \multirow{3}{*}{ Orta } \\
\hline & Orta & $0 / 0.25 / 0.375 / 0.5$ & 0.5 & & \\
\hline & Yüksek & $0.125 / 0.375$ & 0.375 & & \\
\hline \multirow{3}{*}{ 3. Sinif } & Düşük & $0.125 / 0.25 / 0.5$ & 0.5 & \multirow{3}{*}{11.27} & \multirow{3}{*}{ Orta } \\
\hline & Orta & $0 / 0.125 / 0.25 / 0.375 / 0.5$ & 0.5 & & \\
\hline & Yüksek & $0 / 0.25 / 0.375$ & 0.375 & & \\
\hline
\end{tabular}

Üç sınıfın pazarlama yetenekleri değerlendirildiğinde, 2. sınıf ve 3. sınıfın pazarlama yeteneklerinin aynı ve orta düzeyde olduğu, buna karşın 1. sınıfın puanının daha düşük olduğu ve orta ile düşük sınıf arasında yer aldığ belirlenmiştir. Üç sınıfında pazarlama yetenekleri geliştirilerek yüksek sınıfına çıkarılması, özellikle 1. sınıfın pazarlama yeteneklerini arttıracak şekilde eğitilmeleri önemlidir. 


\subsubsection{Finans Yeteneği Düzeyinin Bulanık Mantık Yaklaşımıyla Ölçülmesi}

Finans yeteneği üç madde ile ölçüldüğünden bu değişken kapsamında bir kişi en az 3 ve en yüksek 15 puan alabilmektedir. Bu değişken kapsamında üçgensel üyelik fonksiyonu kullanılmış ve düşük, orta, yüksek olmak üzere 3 küme belirlenmiştir. Herbir dilsel değişkenin üyelik fonksiyonları Şekil 6'da görülmektedir.

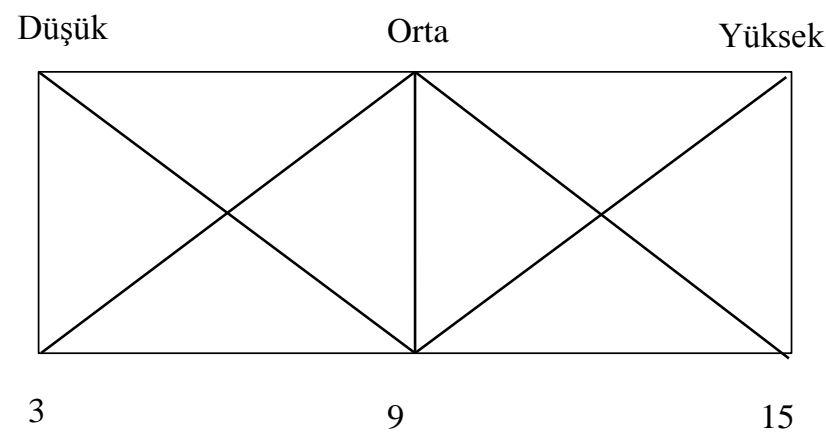

Şekil 6: Finans Yeteneği Değişkenine Ait Üyelik Fonksiyonları

$$
\begin{aligned}
& \mu_{\text {düsük }}=\left\{\begin{array}{ccc}
0 & , & x \geq 9 \\
\frac{9-x}{6} & , & 3<x<9 \\
1 & , & x=3
\end{array}\right\} \quad \mu_{\text {orta }}=\left\{\begin{array}{ccc}
0, & x=3, x=15 \\
\frac{x-3}{6}, & 3<x<9 \\
1, & x=9 \\
\frac{15-x}{6}, & 9<x<15
\end{array}\right\} \\
& \mu_{y \ddot{u k s e k}}=\left\{\begin{array}{ccc}
0 & , & x \leq 9 \\
\frac{x-9}{6} & , & 9<x<15 \\
1 & , & x=15
\end{array}\right\}
\end{aligned}
$$

Finans yeteneği değişkeni çerçevesinde herbir sınıftaki herbir girişimciye ait puanlar ve puanlara ait üyelik dereceleri aşağıdaki Tablo 7'de görülmektedir. 
Tablo 7: Finans Yeteneği Değişkenine İlişkin Üyelik Dereceleri

\begin{tabular}{|c|c|c|c|c|c|c|c|c|c|c|c|c|}
\hline \multirow{2}{*}{ G } & \multicolumn{4}{|c|}{ 1. Sinif } & \multicolumn{4}{|c|}{ 2. Sinif } & \multicolumn{4}{|c|}{ 3. Sinif } \\
\hline & $\mathrm{P}$ & D & $\mathrm{O}$ & Y & $\mathrm{P}$ & D & $\mathrm{O}$ & Y & $\mathrm{P}$ & D & $\mathrm{O}$ & Y \\
\hline 1 & 4 & 0.833 & 0.166 & - & 4 & 0.833 & 0.166 & - & 3 & 1 & 0 & - \\
\hline 2 & 4 & 0.833 & 0.166 & - & 5 & 0.666 & 0.333 & - & 3 & 1 & 0 & - \\
\hline 3 & 5 & 0.666 & 0.333 & - & 5 & 0.666 & 0.333 & - & 4 & 0.833 & 0.166 & - \\
\hline 4 & 6 & 0.500 & 0.500 & - & 5 & 0.666 & 0.333 & - & 5 & 0.666 & 0.333 & - \\
\hline 5 & 6 & 0.500 & 0.500 & - & 6 & 0.500 & 0.500 & - & 6 & 0.500 & 0.500 & - \\
\hline 6 & 6 & 0.500 & 0.500 & - & 6 & 0.500 & 0.500 & - & 6 & 0.500 & 0.500 & - \\
\hline 7 & 6 & 0.500 & 0.500 & - & 6 & 0.500 & 0.500 & - & 6 & 0.500 & 0.500 & - \\
\hline 8 & 6 & 0.500 & 0.500 & - & 7 & 0.333 & 0.666 & - & 6 & 0.500 & 0.500 & - \\
\hline 9 & 7 & 0.333 & 0.666 & - & 9 & - & 1 & 0 & 6 & 0.500 & 0.500 & - \\
\hline 10 & 7 & 0.333 & 0.666 & - & 9 & - & 1 & 0 & 6 & 0.500 & 0.500 & - \\
\hline 11 & 7 & 0.333 & 0.666 & - & 9 & - & 1 & 0 & 7 & 0.333 & 0.666 & - \\
\hline 12 & 7 & 0.333 & 0.666 & - & 9 & - & 1 & 0 & 7 & 0.333 & 0.666 & - \\
\hline 13 & 7 & 0.333 & 0.666 & - & 10 & - & 0.833 & 0.166 & 7 & 0.333 & 0.666 & - \\
\hline 14 & 7 & 0.333 & 0.666 & - & 11 & - & 0.666 & 0.333 & 8 & 0.166 & 0.833 & - \\
\hline 15 & 7 & 0.333 & 0.666 & - & 11 & - & 0.666 & 0.333 & 8 & 0.166 & 0.833 & - \\
\hline 16 & 7 & 0.333 & 0.666 & - & 11 & - & 0.666 & 0.333 & 8 & 0.166 & 0.833 & - \\
\hline 17 & 7 & 0.333 & 0.666 & - & 11 & - & 0.666 & 0.333 & 8 & 0.166 & 0.833 & - \\
\hline 18 & 7 & 0.333 & 0.666 & - & 11 & - & 0.666 & 0.333 & 8 & 0.166 & 0.833 & - \\
\hline 19 & 8 & 0.166 & 0.833 & - & 11 & - & 0.666 & 0.333 & 8 & 0.166 & 0.833 & - \\
\hline 20 & 8 & 0.166 & 0.833 & - & 12 & - & 0.500 & 0.500 & 8 & 0.166 & 0.833 & - \\
\hline 21 & 8 & 0.166 & 0.833 & - & 12 & - & 0.500 & 0.500 & 9 & - & 1 & 0 \\
\hline 22 & 8 & 0.166 & 0.833 & - & 13 & - & 0.333 & 0.666 & 9 & - & 1 & 0 \\
\hline 23 & 8 & 0.166 & 0.833 & - & 13 & - & 0.333 & 0.666 & 10 & - & 0.833 & 0.166 \\
\hline 24 & 8 & 0.166 & 0.833 & - & 13 & - & 0.333 & 0.666 & 10 & - & 0.833 & 0.166 \\
\hline 25 & 8 & 0.166 & 0.833 & - & 13 & - & 0.333 & 0.666 & 11 & - & 0.666 & 0.333 \\
\hline 26 & 9 & - & 1,000 & 0 & 13 & - & 0.333 & 0.666 & 11 & - & 0.666 & 0.333 \\
\hline 27 & 9 & - & 1,000 & 0 & 13 & - & 0.333 & 0.666 & 12 & - & 0.500 & 0.500 \\
\hline 28 & 10 & - & 0.833 & 0.166 & 14 & - & 0.166 & 0.833 & 12 & - & 0.500 & 0.500 \\
\hline 29 & 10 & - & 0.833 & 0.166 & 15 & - & 0 & 1 & 13 & - & 0.333 & 0.666 \\
\hline 30 & 11 & - & 0.666 & 0.333 & 15 & - & 0 & 1 & 13 & - & 0.333 & 0.666 \\
\hline
\end{tabular}

Herbir puana ait üyelik dereceleri belirlendikten sonra çıktı değerini elde etmek için kullanılan min-max çıkarım yöntemi ile elde edilen sonuçlar ile durulaştırma değerleri Tablo 8'de yer almaktadır. 
Tablo 8: Finans Yeteneği Değişkenine Ait Min-Max Çıkarım

\begin{tabular}{|c|c|c|c|c|c|}
\hline Siniflar & Kümeler & Min. Değerler & $\begin{array}{c}\text { Min-Max } \\
\text { Çıkarım }\end{array}$ & $\begin{array}{l}\text { Durulaştırılmış } \\
\text { Değer }\end{array}$ & Sonuç \\
\hline \multirow{3}{*}{ 1. Sinif } & Düsük & $0.166 / 0.333 / 0.5$ & 0.5 & \multirow{3}{*}{8.14} & \multirow{3}{*}{ Orta } \\
\hline & Orta & $0.166 / 0.333$ & 0.333 & & \\
\hline & Yüksek & $0 / 0.166 / 0.333$ & 0.333 & & \\
\hline \multirow{3}{*}{ 2. Sinif } & Düşük & $0.333 / 0.5$ & 0.5 & \multirow{3}{*}{8.24} & \multirow{3}{*}{ Orta } \\
\hline & Orta & $0 / 0.166 / 0.333 / 0.5$ & 0.5 & & \\
\hline & Yüksek & $0 / 0.166 / 0.333$ & 0.333 & & \\
\hline \multirow{3}{*}{ 3. Sinif } & Düşük & $0.166 / 0.333 / 0.5$ & 0.5 & \multirow{3}{*}{8.24} & \multirow{3}{*}{ Orta } \\
\hline & Orta & $0 / 0.166 / 0.333 / 0.5$ & 0.5 & & \\
\hline & Yüksek & $0 / 0.166 / 0.333$ & 0.333 & & \\
\hline
\end{tabular}

Finans yeteneği değişkenine ait Tablo 8'de yer alan sonuçlar incelendiğinde; 2. sınıf ve 3. sınıfın finans yeteneklerinin aynı olduğu, 1. sınıfın biraz daha düşük olduğu görülmektedir. Tüm sınıfların finans yeteneklerinin orta düzeyde olduğu belirlenmiş ve tüm sınıfların finans yeteneklerini yüksek düzeye çıkarmak için eğitilmelerine önem verilmesi gerekmektedir.

\subsubsection{Teknik Yetenek Düzeyinin Bulanık Mantık Yaklaşımıyla Ölçülmesi}

Finans yeteneği üç madde ile ölçüldüğünden bu değişken kapsamında bir kişi en az 3 ve en yüksek 15 puan alabilmektedir. Bu değişken kapsamında üçgensel üyelik fonksiyonu kullanılmış ve düşük, orta, yüksek olmak üzere 3 küme belirlenmiştir. Herbir dilsel değişkenin üyelik fonksiyonları Şekil 7'de görülmektedir.

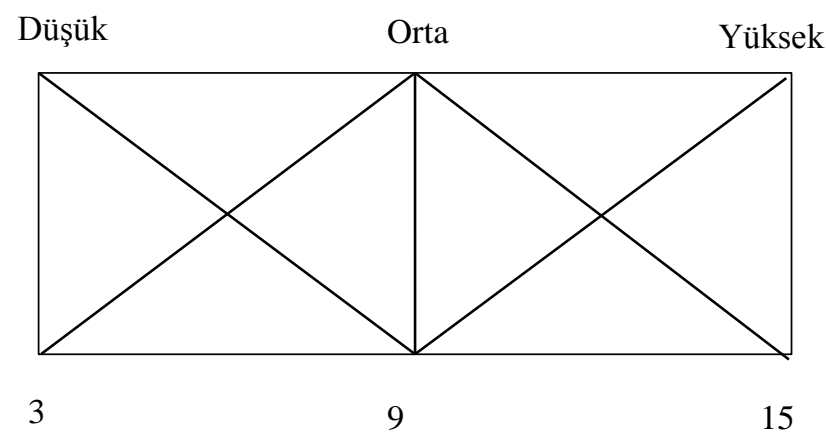

Şekil 7: Teknik Yetenek Değişkenine Ait Üyelik Fonksyionları 


$$
\begin{aligned}
& \mu_{\text {düsük }}=\left\{\begin{array}{ccc}
0 & , & x \geq 9 \\
\frac{9-x}{6} & , & 3<x<9 \\
1, & x=3
\end{array}\right\} \quad \mu_{\text {orta }}=\left\{\begin{array}{ccc}
0 & , & x=3, x=15 \\
\frac{x-3}{6} & , & 3<x<9 \\
1, & x=9 \\
\frac{15-x}{6} & , & 9<x<15
\end{array}\right\} \\
& \mu_{y u ̈ k s e k}=\left\{\begin{array}{ccc}
0 & , & x \leq 9 \\
\frac{x-9}{6} & , & 9<x<15 \\
1 & , & x=15
\end{array}\right\}
\end{aligned}
$$

Teknik yetenek değişkeni çerçevesinde herbir sınıftaki herbir girişimciye ait puanlar ve puanlara ait üyelik dereceleri aşağıdaki Tablo 9'da görülmektedir.

Tablo 9: Teknik Yetenek Değişkenine İlişsin Üyelik Dereceleri

\begin{tabular}{|c|c|c|c|c|c|c|c|c|c|c|c|c|}
\hline \multirow{2}{*}{ G } & \multicolumn{4}{|c|}{1 Sinıf } & \multicolumn{4}{|c|}{ 2. Sinıf } & \multicolumn{4}{c|}{ 3. Sinıf } \\
\cline { 2 - 15 } & $\mathrm{P}$ & $\mathrm{D}$ & $\mathrm{O}$ & $\mathrm{Y}$ & $\mathrm{P}$ & $\mathrm{D}$ & $\mathrm{O}$ & $\mathrm{Y}$ & $\mathrm{P}$ & $\mathrm{D}$ & $\mathrm{O}$ & $\mathrm{Y}$ \\
\hline 1 & 3 & 1 & 0 & - & 3 & 1 & 0 & - & 3 & 1 & 0 & - \\
\hline 2 & 5 & 0.666 & 0.333 & - & 3 & 1 & 0 & - & 3 & 1 & 0 & - \\
\hline 3 & 5 & 0.666 & 0.333 & - & 3 & 1 & 0 & - & 4 & 0.833 & 0.166 & - \\
\hline 4 & 5 & 0.666 & 0.333 & - & 3 & 1 & 0 & - & 4 & 0.833 & 0.166 & - \\
\hline 5 & 5 & 0.666 & 0.333 & - & 3 & 1 & 0 & - & 6 & 0.500 & 0.500 & - \\
\hline 6 & 5 & 0.666 & 0.333 & - & 3 & 1 & 0 & - & 7 & 0.333 & 0.666 & - \\
\hline 7 & 5 & 0.666 & 0.333 & - & 3 & 1 & 0 & - & 7 & 0.333 & 0.666 & - \\
\hline 8 & 5 & 0.666 & 0.333 & - & 3 & 1 & 0 & - & 7 & 0.333 & 0.666 & - \\
\hline 9 & 6 & 0.500 & 0.500 & - & 3 & 1 & 0 & - & 7 & 0.333 & 0.666 & - \\
\hline 10 & 6 & 0.500 & 0.500 & - & 3 & 1 & 0 & - & 7 & 0.333 & 0.666 & - \\
\hline 11 & 6 & 0.500 & 0.500 & - & 4 & 0.833 & 0.166 & - & 7 & 0.333 & 0.666 & - \\
\hline 12 & 7 & 0.333 & 0.666 & - & 5 & 0.666 & 0.333 & - & 7 & 0.333 & 0.666 & - \\
\hline 13 & 8 & 0.166 & 0.333 & - & 7 & 0.333 & 0.666 & - & 8 & 0.166 & 0.833 & - \\
\hline 14 & 8 & 0.166 & 0.333 & - & 7 & 0.333 & 0.666 & - & 10 & - & 0.833 & 0.166 \\
\hline 15 & 9 & - & 1 & 0 & 7 & 0.333 & 0.666 & - & 10 & - & 0.833 & 0.166 \\
\hline 16 & 9 & - & 1 & 0 & 9 & - & 1 & 0 & 10 & - & 0.833 & 0.166 \\
\hline 17 & 9 & - & 1 & 0 & 9 & - & 1 & 0 & 11 & - & 0.666 & 0.333 \\
\hline 18 & 11 & - & 0.666 & 0.333 & 9 & - & 1 & 0 & 11 & - & 0.666 & 0.333 \\
\hline 19 & 11 & - & 0.666 & 0.333 & 10 & - & 0.833 & 0.166 & 11 & - & 0.666 & 0.333 \\
\hline
\end{tabular}


Tablo 9: Teknik Yetenek Değişkenine İlişkin Üyelik Dereceleri (Devamı)

\begin{tabular}{|c|c|c|c|c|c|c|c|c|c|c|c|c|}
\hline \multirow{2}{*}{$\mathrm{G}$} & \multicolumn{4}{|c|}{ 1. Sinıf } & \multicolumn{4}{|c|}{ 2. Sinıf } & \multicolumn{4}{c|}{ 3. Sinıf } \\
\cline { 2 - 15 } & $\mathrm{P}$ & $\mathrm{D}$ & $\mathrm{O}$ & $\mathrm{Y}$ & $\mathrm{P}$ & $\mathrm{D}$ & $\mathrm{O}$ & $\mathrm{Y}$ & $\mathrm{P}$ & $\mathrm{D}$ & $\mathrm{O}$ & $\mathrm{Y}$ \\
\hline 20 & 11 & - & 0.666 & 0.333 & 11 & - & 0.666 & 0.333 & 11 & - & 0.666 & 0.333 \\
\hline 21 & 11 & - & 0.666 & 0.333 & 11 & - & 0.666 & 0.333 & 11 & - & 0.666 & 0.333 \\
\hline 22 & 11 & - & 0.666 & 0.333 & 12 & - & 0.500 & 0.500 & 11 & - & 0.666 & 0.333 \\
\hline 23 & 12 & - & 0.500 & 0.500 & 12 & - & 0.500 & 0.500 & 13 & - & 0.333 & 0.666 \\
\hline 24 & 12 & - & 0.500 & 0.500 & 12 & - & 0.500 & 0.500 & 13 & - & 0.333 & 0.666 \\
\hline 25 & 13 & - & 0.333 & 0.666 & 13 & - & 0.333 & 0.666 & 13 & - & 0.333 & 0.666 \\
\hline 26 & 14 & - & 0.166 & 0.833 & 13 & - & 0.333 & 0.666 & 14 & - & 0.166 & 0.833 \\
\hline 27 & 15 & - & 1 & 0 & 13 & - & 0.333 & 0.666 & 14 & - & 0.166 & 0.833 \\
\hline 28 & 15 & - & 1 & 0 & 14 & - & 0.166 & 0.833 & 15 & - & 0 & 1 \\
\hline 29 & 15 & - & 1 & 0 & 15 & - & 1 & 0 & 15 & - & 0 & 1 \\
\hline 30 & 15 & - & 1 & 0 & 15 & - & 1 & 0 & 15 & - & 0 & 1 \\
\hline
\end{tabular}

Herbir puana ait üyelik dereceleri belirlendikten sonra çıktı değerini elde etmek için kullanılan min-max çıkarım yöntemi ile elde edilen sonuçlar ile durulaştırma değerleri Tablo 10'da yer almaktadır.

Tablo 10: Teknik Yetenek Değişkenine Ait Min-Max Çıkarım

\begin{tabular}{|c|c|c|c|c|c|}
\hline Siniflar & Kümeler & Min. Değerler & $\begin{array}{c}\text { Min-Max } \\
\text { Çıkarım }\end{array}$ & $\begin{array}{l}\text { Durulaştırılmış } \\
\text { Değer }\end{array}$ & Sonuç \\
\hline \multirow{3}{*}{ 1. Sinif } & Düşük & $0.166 / 0.333 / 0.5$ & 0.5 & \multirow{3}{*}{8.24} & \multirow{3}{*}{ Orta } \\
\hline & Orta & $0 / 0.166 / 0.333 / 0.5$ & 0.5 & & \\
\hline & Yüksek & $0 / 0.333$ & 0.333 & & \\
\hline \multirow{3}{*}{ 2. Sinif } & Düşük & 0.333 & 0.333 & \multirow{3}{*}{9} & \multirow{3}{*}{ Orta } \\
\hline & Orta & $0 / 0.166 / 0.333 / 0.5$ & 0.5 & & \\
\hline & Yüksek & $0 / 0.166 / 0.333$ & 0.333 & & \\
\hline \multirow{3}{*}{ 3. Sinif } & Düşük & $0.166 / 0.333 / 0.5$ & 0.5 & \multirow{3}{*}{8.14} & \multirow{3}{*}{ Orta } \\
\hline & Orta & $0 / 0.166 / 0.333$ & 0.333 & & \\
\hline & Yüksek & $0.166 / 0.333$ & 0.333 & & \\
\hline
\end{tabular}

Teknik yetenek değişkeni değerlendirildiğinde, üç sınıfın da düzeylerinin orta düzeyde olduğu görülmektedir. Tüm sınıfların teknik yeteneği yüksek sınıfına çıkarılmak için eğitilmeleri önem arz etmektedir. 


\subsubsection{Genel Girişimcilik Kapasitesinin Bulanık Mantık Yaklaşımıyla Ölçülmesi}

Genel girişimcilik kapasitesini ölçmek için temel iş yetenekleri, pazarlama yeteneği, finans yeteneği ve teknik yetenek değişkenlerinin tümü dikkate alınmıştır. Girişimcilik kapasitesi ondört madde ile ölçüldüğünden bu değişken kapsamında bir kişi en az 14 ve en yüksek 70 puan alabilmektedir. Bu değişken kapsamında üçgensel üyelik fonksiyonu kullanılmış ve çok düşük, düşük, orta, yüksek, çok yüksek olmak üzere 5 küme belirlenmiştir. Herbir dilsel değişkenin üyelik fonksiyonları aşağıda Şekil 8'de görülmektedir.

Çok Düşük

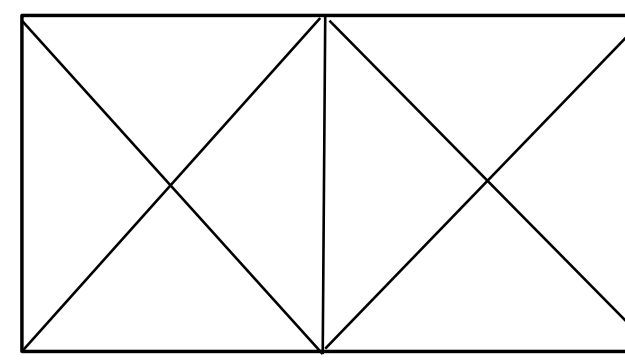

14

28

Orta

Yüksek

Çok Yüksek

Şekil 8: Genel Girişimcilik Değişkenine Ait Üyelik Fonksiyonları

$$
\begin{aligned}
& \mu_{\text {cokdüsük }}=\left\{\begin{array}{ccc}
0 & , & x \geq 28 \\
\frac{28-x}{14} & , & 14<x<28 \\
1 & , & x=14
\end{array}\right\} \quad \mu_{\text {düsük }}=\left\{\begin{array}{ccc}
0 & , & x=14, x \geq 42 \\
\frac{x-14}{14} & , & 14<x<28 \\
1 & , & x=28 \\
\frac{42-x}{14} & , & 28<x<42
\end{array}\right\} \\
& \mu_{\text {orta }}=\left\{\begin{array}{ccc}
0 & , & x \leq 28, x \geq 56 \\
\frac{x-28}{14} & , & 28<x<42 \\
1 & , & x=42 \\
\frac{56-x}{14} & , & 42<x<56
\end{array}\right\} \quad \mu_{\text {yïksek }}=\left\{\begin{array}{ccc}
0 & , & x \leq 42, x=70 \\
\frac{x-42}{14} & , & 42<x<56 \\
1 & , & x=56 \\
\frac{70-x}{14} & , & 56<x<70
\end{array}\right\} \\
& \mu_{\text {cokyüksek }}=\left\{\begin{array}{ccc}
0 & , & x \leq 56 \\
\frac{x-56}{14} & , & 56<x<70 \\
1 & , & x=70
\end{array}\right\}
\end{aligned}
$$


Çakın, E.

Bahar/Spring 2019

Cilt 9, Say1 1, ss. 245-275

Volume 9, Issue 1, pp. 245-275

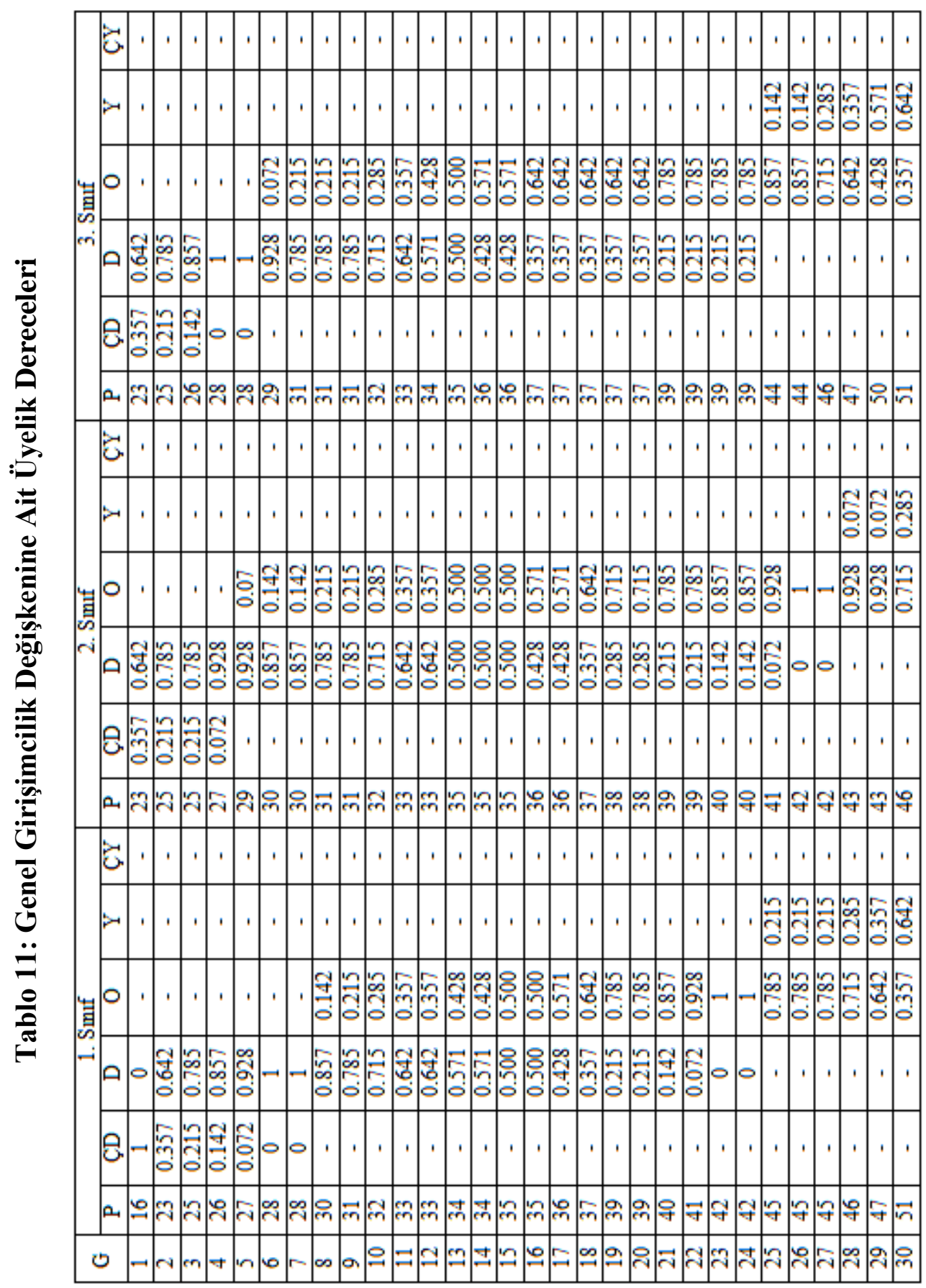


Genel girişimcilik değişkeni çerçevesinde her bir sınıftaki her bir girişimciye ait puanlar ve puanlara ait üyelik dereceleri aşağıdaki Tablo 11'de görülmektedir.

Genel girişimcilik kapasitesi sonuçlarının yer aldığı Tablo 12 incelendiğinde, üç sınıfın da girişimcilik kapasitesinin düşük düzeyde olduğu görülmektedir. Temel iş yetenekleri, pazarlama yeteneği, finans yeteneği ve teknik yetenek değişkenleri arttırılarak tüm sınıfların girişimcilik kapasitelerinin yükseltilmesi gerekmektedir.

Tablo 12: Genel Girişimcilik Değişkenine Ait Min-Max Çıkarım

\begin{tabular}{|c|c|c|c|c|c|}
\hline Siniflar & Kümeler & Min. Değerler & $\begin{array}{c}\text { Min- } \\
\text { Max } \\
\text { Çıkarım }\end{array}$ & $\begin{array}{l}\text { Durulaştırılmış } \\
\text { Değer }\end{array}$ & Sonuç \\
\hline \multirow{5}{*}{ 1. Sinif } & Çok Düşük & $0.072 / 0.142 / 0.215 / 0.357$ & 0.357 & \multirow{5}{*}{34.69} & \multirow{5}{*}{ Düşük } \\
\hline & Düşük & $0 / 0.072 / 0.142 / 0.215 / 0.357 / 0.428 / 0.5$ & 0.5 & & \\
\hline & Orta & $0.142 / 0.215 / 0.285 / 0.357 / 0.428$ & 0.428 & & \\
\hline & Yüksek & $0.215 / 0.285 / 0.357$ & 0.357 & & \\
\hline & $\begin{array}{l}\text { Çok } \\
\text { Yüksek }\end{array}$ & 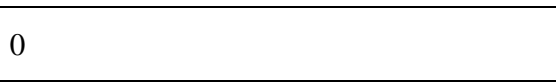 & 0 & & \\
\hline \multirow{5}{*}{ 2. Sinif } & Çok Düşük & $0.072 / 0.215 / 0.357$ & 0.357 & \multirow{5}{*}{33.32} & \multirow{5}{*}{ Düşük } \\
\hline & Düşük & $0 / 0.072 / 0.142 / 0.215 / 0.285 / 0.357 / 0.428 / 0.5$ & 0.5 & & \\
\hline & Orta & $0.072 / 0.142 / 0.215 / 0.285 / 0.357$ & 0.357 & & \\
\hline & Yüksek & $0.072 / 0.285$ & 0.285 & & \\
\hline & $\begin{array}{l}\text { Çok } \\
\text { Yüksek }\end{array}$ & 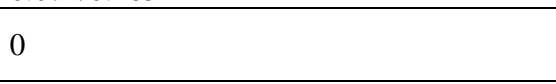 & 0 & & \\
\hline \multirow{5}{*}{ 3. Sinif } & Çok Düşük & $0 / 0.142 / 0.215 / 0.357$ & 0.357 & \multirow{5}{*}{33.71} & \multirow{5}{*}{ Düşük } \\
\hline & Düşük & $0.215 / 0.357 / 0.428 / 0.5$ & 0.5 & & \\
\hline & Orta & $0.072 / 0.215 / 0.285 / 0.357 / 0.428$ & 0.428 & & \\
\hline & Yüksek & $0.142 / 0.285$ & 0.285 & & \\
\hline & $\begin{array}{l}\text { Çok } \\
\text { Yüksek }\end{array}$ & 0 & 0 & & \\
\hline
\end{tabular}

\subsubsection{Bulanık Mantık Yaklaşımının Klasik Yöntem İle Karşılaştırılması}

Bulanık mantık yaklaşımı dilsel değişkenler ile insan düşünce sistemini kullandığından birçok yönteme göre önemli avantajları bulunmaktadır. Bulanık mantık yaklaşımı ile elde edilen sonuçlar klasik yöntem ile karşılaştırılarak aşağıdaki Tablo 13 elde edilmiştir. Klasik yöntem olarak basit aritmetik ortalama tekniği kullanılmıştır.

Tablo 13: Bulanık Mantık ile Klasik Yöntemin Karşılaştırılması

\begin{tabular}{|l|c|c|c|c|c|c|}
\hline \multirow{2}{*}{\multicolumn{1}{|c|}{ Değişkenler }} & \multicolumn{3}{c|}{ Klasik Yöntem } & \multicolumn{3}{c|}{ Bulanık Mantık } \\
\cline { 2 - 7 } & 1. Sınıf & 2. Sınıf & 3. Sınıf & 1. Sınıf & 2. Sınıf & 3. Sınıf \\
\hline Temel İş Yeteneği & 11.20 & 7.76 & 8.60 & 10.40 & 6.75 & 8.22 \\
\hline Pazarlama Yeteneği & 7.96 & 9.40 & 9.93 & 8.00 & 11.27 & 11.27 \\
\hline Finans Yeteneği & 7.26 & 10.06 & 7.93 & 8.14 & 8.24 & 8.24 \\
\hline Teknik Yetenek & 9.06 & 7.93 & 9.50 & 8.24 & 9.00 & 8.14 \\
\hline Genel Girişimcilik Kapasitesi & 35.50 & 35.13 & 36.03 & 34.69 & 33.32 & 33.71 \\
\hline
\end{tabular}


Tablo 13 incelendiğinde, klasik yöntem ile bulanık mantık yaklaşımı sonuçlarının birbirinden farklı olduğu görülmektedir. 1. sınıfın en zayıf olduğu nokta, klasik yönteme göre finans yeteneği iken, bulanık mantık yaklaşımına göre pazarlama yeteneğidir. 2. sinıfin en güçlü olduğu nokta klasik yönteme göre finans yeteneğiyken, bulanık mantığa göre pazarlama yeteneğidir. Bununla beraber 3 . sınıfın en zayıf olduğu nokta klasik yönteme göre finans yeteneğiyken, bulanık mantığa göre teknik yetenektir. Klasik yöntem, temel matematiksel kalıplara bağlı kaldığından esnek değildir. Bulanık mantık yaklaşımı ise daha esnek ve daha tutarlı sonuçlara ulaştıran bir yaklaşımdır.

\section{Sonuç ve Öneriler}

Ülkelerin sürdürülebilir rekabet avantajı elde etmesinde yararlandıkları en önemli stratejilerden biri girişimcilik odaklı politikalardır. Tüm ülkeler girişimciliği destekleyerek önemli kazanımlar elde etmek istemektedirler. Ülkemizin de kalkınması ve büyümesi girişimciliğe ve girişimcilere verdiği değere bağlı olarak şekillenecektir. $\mathrm{Bu}$ nedenle ülkemizde girişimcilik konusunda her türlü faaliyet KOSGEB tarafından etkin bir şekilde yerine getirilmektedir. KOSGEB tarafından gerçekleştirilen girişimcilik eğitimleri ile hem girişimcilik kapasitesinin yükseltilmesi hem de başarılı ve sürdürülebilir işletmelerin kurulması sağlanmaktadır.

$\mathrm{Bu}$ çalışmada KOSGEB tarafından düzenlenen uygulamalı girişimcilik eğitimlerine katılan girişimci adaylarının eğitimin başlangıcında girişimcilik kapasitelerinin bulanık mantık yaklaşımı ile ölçülmesi ve zayıf olan noktaların tespit edilmesi amaçlanmıştır. Ayrıca bulanık mantık yaklaşımı klasik yöntem ile de karşılaştırılarak bazı önemli avantajlarına değinilmiştir. Araştırma sonuçlarına göre, genel olarak girişimcilik kapasitesinin düşük düzeyde olduğu sonucuna ulaşılmıştır. Benzer şekilde temel iş yeteneği, pazarlama yeteneği, finans yeteneği ve teknik yetenek değişkenlerinin de düşük ve orta düzeyde oldukları belirlenmiştir. Temel iş yeteneğinde en yüksek puana 1. sınıf sahipken, pazarlama ve finans yeteneklerinde 2. ve 3. sinıflar iyi düzeyde, teknik yetenek bakımından ise 2. sınıf daha iyi konumdadır. Eğitim içerikleri belirlenirken güçlü ve zayıf noktaların iyi tespit edilerek her sınıf farklı bir eğitim içeriği ile eğitime tabii tutularak girişimcilik kapasitelerinin arttırılması planlanabilir. İleride gerçekleştirilecek çalışmalarda farklı yapay zeka teknikleri ve çok kriterli karar verme teknikleri kullanılarak girişimcilik kapasitesinin ölçülmesi ve girişimcilik kapasitesini etkileyen temel yeteneklerin belirlenmesi sağlanabilir. 


\section{Kaynakça}

Aksoy, C. ve Yalçınsoy, A. (2017). Üniversite öğrencilerinin girișimcilik eğilimleri üzerine bir araştırma. İşletme Araştırmaları Dergisi, 9(4), 341359.

Asamani, L. ve Mensah, A.O. (2013). Entrepreneurial inclination among ghanaian university students: The case of University of Cape Coast, Ghana. European Journal of Business and Management. 5(19), 113-126

Azimjonov, J., Selvi, İ.H. ve Özbek, U. (2016). Evaluation of distance learning students performance using fuzzy logic. Yönetim Bilişim Sistemleri Dergisi. 1(3), 87-97

Baloch, Q.B., Rahim, F. ve Manzoor, S.R. (2017). Entrepreneurial capacity building and students entrepreneurial inclinatıon. City University Research Journal. 7(2), 285-299

Bandemer, H. Ve Gottwald, S. (1995). Fuzzy sets, fuzzy logic, fuzzy methods with applications. Wiley.

Bıyan, M. ve Bircan, H. (2018). Daha önce geliştirilmiş Likert tipi bir ölçek ile tip-1 ve tip-2 bulanık Likert ölçeğinin sonuçlarının karşılaştırılması. International Journal of Economic and Administrative Studies. 18. EYİ Özel Sayıs1), 369-382.

Brixy, U., Sternberg, R. ve Stüber, H. (2008). From potential to real entrepreneurship. Institut für Arbeitsmarktund Berufsforschung-IAB Discussion Paper. 32/2008.

Chunxia, Y. (2011). Research on Entrepreneurial capacity evaluation index system of the self-employed: based on 603 samples analysis. Proceedings of the 8th International Conference on Innovation \& Management. 30 Kasım-02 Aralık 2011. Kitakyushu, Japonya.

Coduras, A., Saiz-Alvarez, J.M. ve Ruiz, J. (2016). measuring readiness for entrepreneurship: An information tool proposal. Journal of Innovation \& Knowledge. 1, 99-108.

Cooney, T.M. (2012). Entrepreneurship skills for growth-orientated businesses. Report for the Workshop on Skills Development for SMEs and Entrepreneurship'. 28 Kasim 2012. Kopenhag

Curral, L., Santos, S.C. ve Caetano, A. (2013). Theoretical foundations on the entrepreneurial potential. Amity Business Journal. 2(1), 1-11 
Çetin, O. ve Taşdemir, Ö. (2017). Girişimcilik kapasitesi ve bireysel yenilikçiliğin girişimcilik niyeti üzerine etkisi. Social Sciences Research Journal, 6(3), 76-87

Das, P. ve Mukherjee, S. (2017). Designing a fuzzy approach for modelling the performance evaluation of education service providers. Int. J. Services and Operations Management. 26(1), 49-67

Davis, M.H., Hall, J.A. ve Mayer, P.S. (2015). Developing A new measure of entrepreneurial mindset: Reliability, validity and 1mplications for practitioners. Consulting Psychology Journal: Practice and Research. 68(1), 21-48

Gil, M.A., Lubiano, M.A., Rosa de Sáa, S.D.L. ve Sinova, B. (2015). Analyzing data from a fuzzy rating scale-based questionnaire. A case study. Psicothema. 27(2), 182-191

Global Entrepreneurship Monitor (2016/2017). Global Report-2016/2017. Global Entrepreneurship Research Association (GERA).

Güner, N. ve Çomak, E. (2014). Lise öğrencilerinin matematik dersine yönelik tutumlarının bulanık mantık yöntemi ile incelenmesi. Pamukkale Üniversitesi Mühendislik Bilimleri Dergisi. 20(5), 189-196.

Kalayc1, Ş. (2010). SPSS uygulamalı çok değişkenli istatistik teknikleri. 5. Bask1

Keat, O.Y., Selvarajah, C. ve Meyer, D. (2011). Inclination towards entrepreneurship among university students: An empirical study of Malaysian university students. International Journal of Business and Social Science. 2(4), 206-220

Korol, T. ve Korodi, A. (2011). An evaluation of effectiveness of fuzzy logic model in predicting the business bankruptcy. Romanian Journal of Economic Forecasting. 3, 92-107

KOSGEB (2015). Türkiye Girişimcilik Stratejisi ve Eylem Planı (2015-2018). www.kosgeb.gov.tr, (Erişim Tarihi: 07/07/2018)

KOSGEB, TEB ve Yeditepe Üniversitesi (2014). Global Entrepreneurship Monitor-GEM (2014-2016)-Türkiye'de ve Bölgeler'de Girişimcilik. www.kosgeb.gov.tr (Erişim Tarihi: 07/07/2018)

Kutzhanova, N., Lyons, T.S. ve Lichtenstein, G.A. (2009). Skill-based development of entrepreneurs and the role of personal and peer group coaching in enterprise development. Economic Development Quarterly. 23(3), $1-18$ 
Mamabolo, M.A., Kerrin, M. ve Kele, T. (2017). Entrepreneurship management skills requirements in an emerging economy: A South African outlook. The Southern African Journal of Entrepreneurship and Small Business Management. 9(1), 1-10

Sarkar, A., Sahoo, G.ve Sahoo, U.C. (2012). Application of fuzzy logic in transport planning. International Journal on Soft Computing. 3(2), 1-21.

Silva de Souza, G.H., Freire dos Santos, P.C, Lima, N.C., Tavares da Cruz, N.J., Lezana, A.G.R. ve Coelho, J.A.P.M. (2017). Entrepreneurial potential scale: Evidence on confirmatory factor validity, dimensional structure and predictive effectiveness. Gest. Prod São Carlos. 24(2), 324-337

Surya, A.A. Kurian, M. ve Varghese, S.M. (2016). Overall performance evaluation of engineerıng students using fuzzy logic. International Journal on Cybernetics \& Informatics. 5(2), 71-78

Thakre, T.A., Chaudhari, O.K. ve Dhawade, N. (2017). A Fuzzy logic multi criteria approach for evaluation of teachers performance. Advances in Fuzzy Mathematics. 12(1), 129-145

The Global Entrepreneurship Index (2018). The Global Entrepreneurship and Development Institute, Washington, D.C., USA

Upadhyay, J. ve Gautam, P. (2015). Modeling of student's performance evaluaiton. IJIRST -International Journal for Innovative Research in Science \& Technology. 2(3), 94-98

Užga-Rebrovs, O. Ve Kulıešova, G. (2017). Comparative analysis of fuzzy set defuzzification methods in the context of ecological risk assessment. Information Technology and Management Science. 20, 25-29

Vonglao, P. (2017). Application of fuzzy logic to 1mprove the likert scale to measure latent variables. Kasetsart Journal of Social Sciences. 38, 337344.

Wei Ni, L., Ping, L.B., Ying, L.L., Sern, N.H. ve Lih, W.J. (2012). Entrepreneurial intention: A study among students of higher learning institution. Bachelor of Business Administration (HONS). Universiti Tunku Abdul Rahman. Faculty of Business and Finance Department of Business

Yadav, R.S., Soni, A.K. ve Pal, S. (2014). A Study of academic performance evaluation using fuzzy logic techniques. Proceedings of the 8th 
INDIACom; INDIACom-2014 2014 International Conference on “Computing for Sustainable Global Development”, 5th - 7th March, 2014.

Y1lmaz, E. ve Sünbül, A.M. (2009). Üniversite öğrencilerine yönelik girişimcilik ölçeğinin geliştirilmesi. Selçuk Üniversitesi Sosyal Bilimler Enstitüsü Dergisi. 21, 195-203

Yılmaz, M. ve Arslan, E. (2005). Bulanık Mantı̆̆ın jeodezik problemlerin çözümünde kullanılması. Harita ve Kadastro Mühendisleri Odası, Mühendislik Ölçmeleri STB Komisyonu 2. Mühendislik Ölçmeleri Seтроzуити. 23-25 Kasım 2005, İTÜ - İstanbul.

Zadeh, L.A. (1965). Fuzzy Sets. Information and Control. 8, 338-353.

Zahra (2011). Entrepreneurial capability: Opportunity pursuit and game changing. 1nnovation, strategy and structure - Organizations, Institutions, Systems and Regions at Copenhagen Business School. 15-17 Temmuz 2011. Danimarka

Zhang, Y. (2013). Increasing Entrepreneurial Capabilities of Chinese Entrepreneurs in Helsinki Region. Master"es Thesis Degree Programme in International Business Management. Haaga-Helia University of Applied Sciences. 


\title{
Fuzzy Logic Approach For Measuring Entrepreneurship Capacity And An Application
}

\author{
Extended Abstract
}

\section{Introduction}

In recent years, the development levels of countries are determined by the importance given to entrepreneurship activities, the value given to entrepreneurs, new and added-value products produced by entrepreneurs and business environments they create. Countries that want to be in a strong position on a global scale can create a significant competitive advantage against its competitors by supporting entrepreneurial activities and continuously increasing the number of qualified entrepreneurs. Nowadays, considering that countries are competing like businesses, it is inevitable that entrepreneurship is one of the important policies that countries should focus on. Carrying out effectively and maintaining successfully of entrepreneurship activities in a country depends on the entrepreneurial capabilities and entrepreneurial capacity of the human resources of the countries.

In this study, it is aimed to measure entrepreneurial capacity with fuzzy logic approach. In addition, the results obtained with fuzzy logic approach are examined comparatively with classical methods and the fuzzy logic approach are discussed.

\section{Method}

Fuzzy logic is an approach that works in harmony with human thought system and models uncertain processes consistently. Fuzzy logic is a branch of logic which design to represent knowledge and the human mind in a way that computers can process (Yadav vd., 2014, 55). The concept of fuzzy logic was first introduced by Zadeh in 1965 with the study called "Fuzzy Sets" (Zadeh, 1965). Later, it was developed by Zadeh (1973) and Mamdani and Assilian (1975). Zadeh put forward the concept of "Approximate Reasoning" and successfully demonstrated that algorithms that can use ambiguous data to generate ambiguous inferences with uncertain logical expressions. He also thought that fuzzy logic approach could be useful in all complex systems (Sarkar vd., 2012, 2).

In this study, it is aimed to measure entrepreneurial capacity with the fuzzy logic approach and compare it with the classical method. All data is collected by questionnaire to measure the entrepreneurial capacity. The survey consists of two parts. In the first part, demographic questions such as gender, age, marital status, educational status are included. In the second part, there are questions about entrepreneurship skills used in measuring entrepreneurship capacity. Four key variables are taken into account as entrepreneurial skills: core business skills, marketing skills, financial skills and technical skills. The survey is prepared by benefiting from the study of Mamabolo vd. (2017). There are four questions to measure core business abilities, four questions to measure your marketing skills, three questions to measure your finance skills, and three questions to measure your technical skills. The questions asked to measure entrepreneurship capacity are prepared in 5-point Likert scale $(1=$ Strongly disagree, $5=$ Strongly agree $)$. All data included in the study are obtained from entrepreneurial candidates who participate in applied entrepreneurship trainings. Within the scope of entrepreneurship education, 3 classes are determined. 30 people are trained in each class and data are collected from 90 people in total. The levels of core business skills, marketing skills, finance skills and technical skills of each class and their general entrepreneurship capacity is determined. 


\section{Results and Discussion}

The performance score of each entrepreneur is determined by the sum of the answers given to the questions in the survey. On the Likert scale, the score given for each question can be at least 1 and the highest is 5 . The triangular membership function is used in all variables.

Core business skills scores, from high to low, are as follows: 1st class, 3rd class and 2nd class. The first class is closer to the middle cluster and the second class is closer to the lower cluster. 3rd class can be considered as between lower cluster and medium cluster.

When the marketing skills scores of the three classes are evaluated, it is found that the marketing capabilities scores of the 2nd and 3rd class are the same and intermediate level, whereas the score of 1 st class is lower and it is between the middle and the low cluster.

When the results of financial skills scores are examined; it is observed that the 1st class and 3rd class finance capabilities scores are the same and the score of 1st class is slightly lower. It is determined that all classes have medium level financial capabilities.

When the technical skills scores are evaluated, it is seen that the levels of the three classes are at the intermediate level.

When the results of the general entrepreneurship capacity is examined, it is seen that the entrepreneurship capacity of all three classes is low.

It is determined that the results of fuzzy logic approach are different from the classical method. The classical method is not flexible because it is based on basic mathematical patterns. Fuzzy logic approach is a more flexible and more consistent approach.

\section{Conclusion}

In this study, it is aimed to determine entrepreneurial capacities of entrepreneur candidates participating in entrepreneurship trainings with fuzzy logic approach and to identify weaknesses. Also, fuzzy logic approach is compared with the classical method and some important advantages are mentioned. Entrepreneurship capabilities of all classes and general entrepreneurship capacities are determined. It is important to determine these levels before the trainings begin. Because, it is possible to determine the strengths and weaknesses and to increase the entrepreneurship capacity by training each class with a different educational content. In the future studies, it is possible to determine the entrepreneurial capacity and to identify the basic skills affecting entrepreneurship capacity by using different artificial intelligence techniques and multi-criteria decision making techniques. 